\title{
Epigenetic targeting of glioma stem cells: Short-term and long-term treatments with valproic acid modulate DNA methylation and differentiation behavior, but not temozolomide sensitivity
}

\author{
GABRIELE RIVA $^{1,2,5^{*}}$, VALENTINA BUTTA ${ }^{1,2,5^{*}}$, CHIARA CILIBRASI $^{1,2,5}$, SIMONA BARONCHELLI $^{1,3}$ \\ SERENA REDAELLI ${ }^{1}$, LEDA DALPRÀ ${ }^{1,4}$, MARIALUISA LAVITRANO ${ }^{1}$ and ANGELA BENTIVEGNA ${ }^{1,5}$ \\ ${ }^{1}$ Department of Surgery and Translational Medicine, University of Milano-Bicocca, I-20900 Monza; \\ ${ }^{2} \mathrm{PhD}$ Program in Neuroscience, University of Milano-Bicocca, I-20126 Milan; ${ }^{3}$ Institute of Genetic and \\ Biomedical Research, National Research Council (IRGB-CNR), I-20138 Milan; ${ }^{4}$ Medical Genetics Laboratory, \\ S. Gerardo Hospital, I-20900 Monza; ${ }^{5}$ NeuroMI, Milan Center of Neuroscience, I-20900 Monza, Italy
}

Received October 28, 2015; Accepted January 20, 2016

DOI: $10.3892 / o r .2016 .4665$

\begin{abstract}
Glioblastoma (GBM) is the most aggressive tumor of the central nervous system. GBM is a fatal tumor, incurable by conventional therapies. One of the factors underlying tumor recurrence and poor long-term survival is the presence of a cancer stem-like cell population, termed glioma stem cells (GSCs), which is particularly resistant to chemotherapy and radiotherapy and supports tumor self-renewal. The aim of the present study was to evaluate the impact and difference in effects of short-term and long-term treatments with valproic acid (VPA), a histone deacetylase inhibitor, on seven GSC lines. We investigated for the first time the changes in the genome-wide DNA methylation profile and the differentiation behavior of GSCs induced by short-term and long-term VPA treatments. Moreover, we verified VPA sensitivity after long-term VPA pretreatment and, notably, the results provide evidence of a subpopulation more resistant to further VPA treatments. Finally, since short-term VPA treatment induced a reversal of the MGMT methylation status, we aimed to sensitize GSCs to temozolomide, the drug commonly used for this
\end{abstract}

Correspondence to: $\mathrm{Dr}$ Angela Bentivegna, Department of Surgery and Translational Medicine, University of Milan-Bicocca, Via Cadore 48, I-20900 Monza, Italy

E-mail: angela.bentivegna@unimib.it

*Contributed equally

Abbreviations: GBM, glioblastoma multiforme; GSCs, glioma stem cells; VPA, valproic acid; HDACi, histone deacetylase inhibitor; TMZ, temozolomide

Key words: glioblastoma, glioma stem cells, epigenetic therapy, valproic acid, differentiation therapy, DNA methylation profile, temozolomide tumor, using this regimen. The overall data highlighted the heterogeneous behavior of GSC lines that is representative of tumor heterogeneity in GBM. The VPA effects were variable among these cell lines in terms of pro-differentiating ability and DNA methylation switch. Here, we attempted to identify a suitable therapy for the eradication of the stem cell subpopulation, which is mandatory to achieve an effective treatment for this tumor. Differentiation-inducing and epigenetic therapies are the most promising approaches to affect the multiple properties of GSCs and, finally, defeat GBM.

\section{Introduction}

Glioblastoma multiforme (GBM) is the most aggressive tumor of the central nervous system and represents over $70 \%$ of all brain malignancies. GBM is incurable by conventional therapeutic strategies (1). In fact, despite recent advances in surgery, radiotherapy and chemotherapy with temozolomide (TMZ) (2), the median survival of glioma patients remains poor and amounts to $\sim 14$ months. One of the factors underlying tumor recurrence and poor long-term survival is the presence of a cancer stem-like cell population, termed glioma stem cells (GSCs), that is particularly resistant to chemotherapy and radiotherapy and supports tumor self-renewal (3). Another explanation for drug resistance can be ascribed to intratumor heterogeneity due to the development of independent clones derived from a unique progenitor $(4,5)$.

Increasing evidence suggests the role of epigenetic events, apart from genetic alterations, in the development and/or progression of several types of tumors, such as gliomas (6-8). The potential reversibility of epigenetic alterations represents an attractive approach to 'reset' the abnormal cancer epigenome by using epigenetic drugs such as histone deacetylase inhibitors (HDACi). Most recent data suggest the role of this class of drugs in tumor growth inhibition, promotion of apoptosis and induction of differentiation $(9,10)$. Total eradication of the stem subpopulation may be achieved by using 
pro-differentiative drugs, which are able to induce differentiation of GSCs affecting their self-renewal capabilities (11). Thus, HDACi can induce de-repression of genes epigenetically silenced in cancer $(12,13)$ and involved in different cellular processes, including cell cycle control, differentiation, DNA repair and apoptosis (14).

Valproic acid (VPA), apart from being an anticonvulsant and mood stabilizing drug, is also an HDACi that has shown potent antitumor effects in a variety of in vitro and in vivo glioma studies (15-18). In recent years, the discovery of the ability of VPA to affect TMZ sensitivity in GBM cell lines suggests the use of this drug as a chemosensitizing agent (19-21).

In the present study, we investigated and compared for the first time the effects of short-term and long-term VPA treatments on cell morphology, differentiation behavior and DNA methylation profile of GSCs. Moreover, we examine whether long-term VPA treatment induces chemoresistance to VPA. Finally, we utilized VPA to chemosensitize the GSC subpopulation to TMZ action.

\section{Materials and methods}

Cell lines and cell culture conditions. The seven GSC lines used in this study (GBM2, GBM7, GBM04, G144, G166, G179 and GliNS2) were isolated from patients affected by GBM $(22,23)$ and, in 2013, our research group characterized their cytogenomic and epigenomic profiles (24). Cells were cultured in neural stem cell-specific medium, and their stem-like properties were periodically monitored, as previously described (22-24). Cells were cultured in an adherent culture condition using $10 \mu \mathrm{g} / \mathrm{ml}$ laminin (Invitrogen) in a proliferation permissive medium composed of Dulbecco's modified Eagle's medium (DMEM)/F-12 and Neurobasal 1:1 (Invitrogen), B-27 supplement without vitamin A (Invitrogen), $2 \mathrm{mM}$ L-glutamine, $10 \mathrm{ng} / \mathrm{ml}$ recombinant human $\mathrm{bFGF}$ and $20 \mathrm{ng} / \mathrm{ml}$ recombinant human EGF (Miltenyi Biotec), $20 \mathrm{UI} /$ $\mathrm{ml}$ penicillin and $20 \mu \mathrm{g} / \mathrm{ml}$ streptomycin (Euroclone).

Drug treatments. Valproic acid (sodium salt; Sigma) was dissolved in sterile water to a stock concentration of $0.5 \mathrm{M}$. Temozolomide (Sigma) was dissolved in sterile DMSO at the final concentration of $0.05 \mathrm{M}$. All drugs were stored at $-20^{\circ} \mathrm{C}$.

In vitro treatments were performed using $2 \mathrm{mM}$ VPA for 24, 48,72, $96 \mathrm{~h}$ and 14 and 30 days; with regard to TMZ, we administered 50, 100, 200 or $400 \mu \mathrm{M} \mathrm{TMZ}$ for 48 or $72 \mathrm{~h}$.

Cell viability by MTT assay. The methyl-thiazolyl tetrazolium (MTT) assay was performed to evaluate VPA efficacy in VPA long-term treated (30 days) cells compared with cells that were not previously treated (naïve). We also performed the cell viability analysis on naïve cells treated with the combination of $2 \mathrm{mM}$ VPA plus several concentrations of TMZ (50, 100,200 and $400 \mu \mathrm{M}$ ) for $96 \mathrm{~h}$. The combined treatment was divided into a pretreatment phase (only VPA for $48 \mathrm{~h}$ ) and a combination phase (VPA plus TMZ for an additional $48 \mathrm{~h}$ ).

Cells were seeded at a density of $4 \times 10^{4}$ cells/well in a 96-well-plate in $100 \mu \mathrm{l}$ of culture medium and incubated at $37^{\circ} \mathrm{C}$. On the following day, we added VPA or TMZ at the selected final concentrations. After 24, 48, 72 and $96 \mathrm{~h}$ of treatment, $100 \mu \mathrm{l}$ of $1 \mathrm{mg} / \mathrm{ml}$ MTT solution (Sigma) was added to each well and incubation was carried out for $3 \mathrm{~h}$ at $37^{\circ} \mathrm{C}$. Therefore, formazan granules were solubilized in absolute ethanol. The dye absorbance was measured spectrophotometrically at a 595-nm wavelength with the FLUOstar Omega microplate reader (BMG Labtech). The percentage of metabolic activity inhibition was determined by comparing the absorbance values of the treated cells with those of the untreated controls: (Treated cell absorbance/untreated cell absorbance) x 100. Results are the mean values of two independent experiments performed in quadruplicate.

Trypan blue dye exclusion assay. GBM2 $\left(0.25 \times 10^{6}\right)$ or G144 cells $\left(0.5 \times 10^{6}\right)$ were seeded in T25 flasks and then treated with different pharmacological regimens: i) $2 \mathrm{mM}$ VPA for $96 \mathrm{~h}$; ii) $50 \mu \mathrm{M}$ or iii) $200 \mu \mathrm{M}$ TMZ for $72 \mathrm{~h}$; iv) $50 \mu \mathrm{M}$ or v) $200 \mu \mathrm{M}$ TMZ for $72 \mathrm{~h}$ after pretreatment with $2 \mathrm{mM}$ VPA for $96 \mathrm{~h}$. Then, cells were harvested and counted to evaluate the number of live cells and cell mortality, using trypan blue dye to discriminate live from dead cells. The results reported are the mean values of three different experiments performed at least in triplicate.

Cooperative index. In order to evaluate the effects of the combined VPA-TMZ treatments, the cooperative index (CI) (26) was calculated comparing the sum of the metabolic activity reduction percentages obtained for each single agent to the percentages obtained upon combined treatments (CI $=\mathrm{VPA} \%+\mathrm{TMZ} \% /$ combined treament cell $\%$ ). $\mathrm{CI}$ values $<1$ indicate a synergistic effect, $\mathrm{CI}$ values $=1$ indicate an additive effect, while CI values $>1$ indicate an antagonistic effect.

Morphological analysis. To evaluate the cellular morphological changes after VPA treatment, cells were seeded in serum-free medium at $3 \times 10^{3}-10^{4}$ cells $/ \mathrm{ml}$, depending on the cell growth rate, specific for each GSC line. After $24 \mathrm{~h}$, cells were treated with $2 \mathrm{mM}$ VPA concentration for 14 and 30 days. Every three days the culture medium was changed and the drug was administered again. The morphological changes were evaluated by phase contrast microscopic observation, comparing VPA-treated and untreated cells. Representative images were captured for each cell line and for each treatment.

Immunofluorescence. The immunofluorescence assays were performed on untreated and $2 \mathrm{mM}$ VPA-treated GSC cultures for 14 and 30 days using rabbit anti-CD133 (1:50; Santa Cruz Biotechnology, Santa Cruz, CA, USA) and mouse anti-nestin (1:50; Millipore, Billerica, MA, USA), rabbit anti-glial fibrillary acidic protein (GFAP, 1:200; Dako), rabbit anti- $\beta$ III-tubulin (1:100; Covance) and goat anti-myelin basic protein (MBP, 1:50; Santa Cruz Biotechnology) as primary antibodies. Alexa Fluor 488-conjugated goat anti-mouse or anti-rabbit (1:200; Molecular Probes, Eugene, OR, USA) was used as the secondary antibody. Alexa Fluor 647-conjugated phalloidin (1:200; Molecular Probes) was used to visualize the actin filaments. Propidium iodide (PI) was used to counterstain the nuclei.

Briefly, untreated cells were placed onto slides by means of Cytospin, while VPA-treated cells spotaneously adhered to the slides. Cells were washed with Dulbecco's modified phosphatebuffered saline (PBS), fixed with $4 \%$ paraformaldehyde for $15 \mathrm{~min}$ and treated for $10 \mathrm{~min}$ with $0.1 \mathrm{M}$ glycine (in PBS). The slides were incubated for $30 \mathrm{~min}$ at room temperature (RT) 

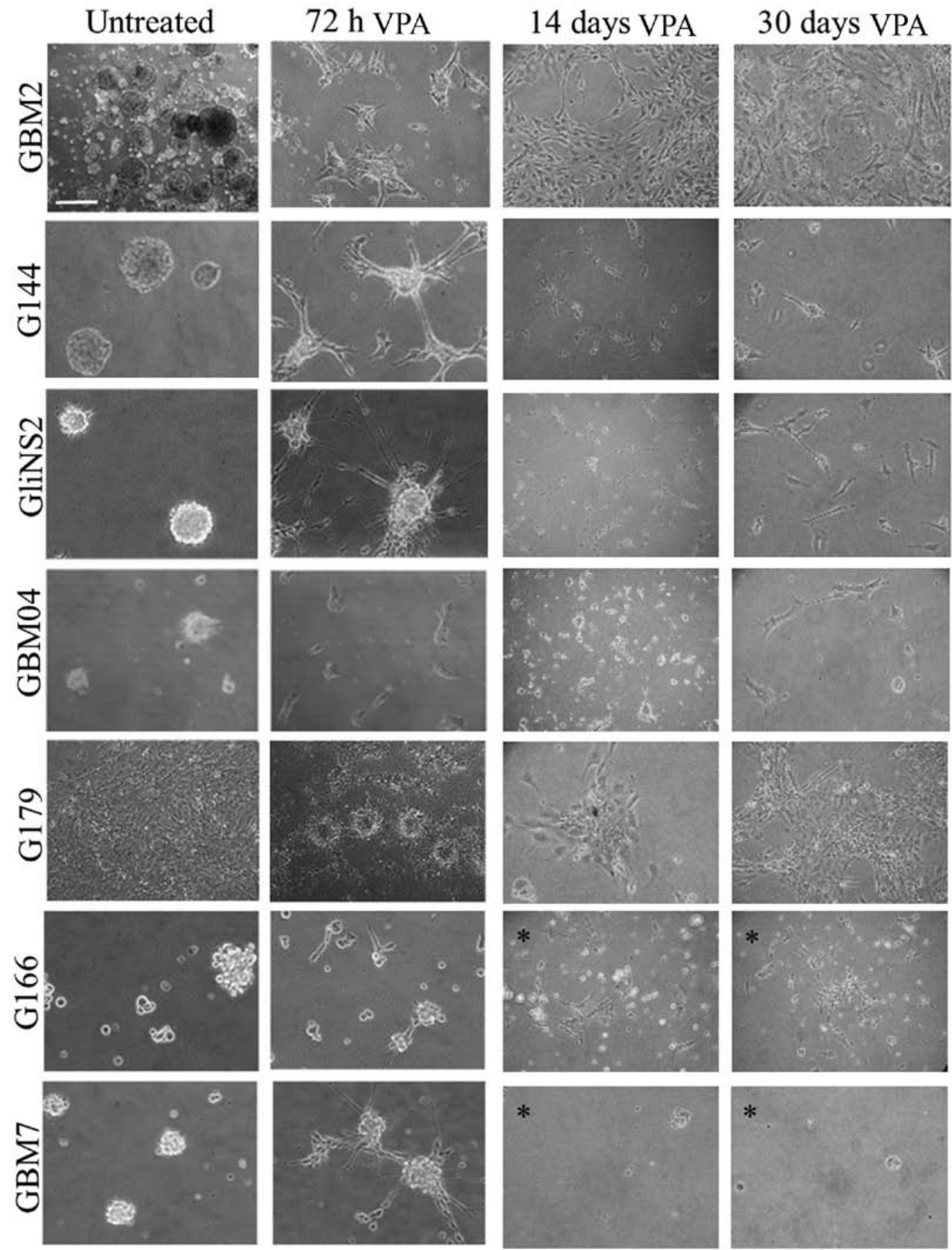

Figure 1. Analysis of cell morphology after valproic acid (VPA) administration. Representative images were captured by phase contrast microscopy of seven glioma stem cell (GSC) lines folllowing treatment with $2 \mathrm{mM}$ VPA for 14 and 30 days. "G166 and GBM7 cells were treated with $1 \mathrm{mM} \mathrm{VPA.} \mathrm{Scale} \mathrm{bar,} 100 \mu \mathrm{m}$.

in blocking solution [5\% bovine serum albumin (BSA), $0.6 \%$ Triton X-100 in PBS] and treated for $30 \mathrm{~min}$ with $70 \mathrm{U} / \mathrm{mg}$ RNAse (1:30; Sigma-Aldrich, Milan, Italy) in blocking solution. Cells were incubated with the primary antibodies at $4^{\circ} \mathrm{C}$ overnight. Then, the slides were rinsed with washing buffer (0.3\% Triton X-100 in PBS) and incubated with secondary fluorescent antibodies, phalloidin and $2.5 \mathrm{mg} / \mathrm{ml}$ PI for $1 \mathrm{~h}$ at RT. The cells were then washed with PBS and coverslips were mounted using polyvinyl alcohol mounting medium (Fluka Analytical, Milan, Italy). Fluorescent cell preparations were examined using a Radiance 2100 confocal microscope (BioRad, Hercules, CA, USA).
In order to perform a quantitative-like analysis, the number of immunereactive cells for each marker was counted, evaluating at least 100 cells/sample over different areas of the slide.

MeDIP-Chip. GBM2 and G144 cell lines were treated with $2 \mathrm{mM}$ VPA for $96 \mathrm{~h}$ and 30 days and then DNA extraction from the control and treated cultures was performed using the Wizard Genomic DNA Purification kit (Promega, Milan, Italy), according to the manufacturer's protocol.

Methylated DNA immunoprecipitation and chip hybridization were performed as previously described (24) following the guidelines of the Agilent Microarray Analysis of Methylated 
Table I. Analysis of stemness and differentiation marker expression in GSC lines.

\begin{tabular}{|c|c|c|c|c|c|c|}
\hline Cell line & Treatment & CD133 (\%) & Nestin (\%) & $\beta I I I$ Tub (\%) & GFAP (\%) & $\operatorname{MBP}(\%)$ \\
\hline \multirow[t]{6}{*}{ GBM2 } & Untreated & 62.96 & 75.44 & 19.27 & 63.81 & 100.00 \\
\hline & $2 \mathrm{mM}$ VPA $72 \mathrm{~h}$ & 56.48 & $53.77^{\mathrm{b}}$ & $36.45^{\mathrm{a}}$ & 64.81 & $94.96^{\mathrm{a}}$ \\
\hline & 2 mM VPA 14 days & $43.39^{\mathrm{a}}$ & $100.00^{c}$ & $100.00^{c}$ & $100.00^{c}$ & $0.00^{c}$ \\
\hline & 2 mM VPA 30 days & $100.00^{c}$ & $100.00^{c}$ & $100.00^{\mathrm{c}}$ & $100.00^{\mathrm{c}}$ & $93.00^{\mathrm{a}}$ \\
\hline & RPMI $10 \%$ FCS 14 days & $97.09^{\mathrm{c}}$ & $100.00^{c}$ & $100.00^{c}$ & $8.26^{\mathrm{c}}$ & 100.00 \\
\hline & RPMI $10 \%$ FCS 30 days & $78.38^{\mathrm{a}}$ & 68.90 & $100.00^{c}$ & $5.93^{c}$ & 100.00 \\
\hline \multirow[t]{6}{*}{ G144 } & Untreated & 78.38 & 91.35 & 45.79 & 82.46 & 100.00 \\
\hline & $2 \mathrm{mM}$ VPA $72 \mathrm{~h}$ & 67.86 & 87.85 & $13.79^{\mathrm{c}}$ & 80.90 & 96.82 \\
\hline & 2 mM VPA 14 days & $32.00^{\mathrm{c}}$ & $0.00^{\mathrm{c}}$ & $100.00^{c}$ & $0.00^{\mathrm{c}}$ & $0.00^{\mathrm{c}}$ \\
\hline & 2 mM VPA 30 days & $0.00^{\mathrm{c}}$ & $0.00^{\mathrm{c}}$ & $18.00^{\mathrm{c}}$ & $32.71^{\mathrm{c}}$ & $0.00^{\mathrm{c}}$ \\
\hline & RPMI $10 \%$ FCS 14 days & $100.00^{c}$ & $100.00^{\mathrm{a}}$ & $0.00^{c}$ & $100.00^{c}$ & 100.00 \\
\hline & RPMI $10 \%$ FCS 30 days & $100.00^{c}$ & $100.00^{\mathrm{a}}$ & $100.00^{c}$ & $100.00^{c}$ & 100.00 \\
\hline \multirow[t]{6}{*}{ G166 } & Untreated & 7.34 & 78.30 & 25.92 & 83.90 & 100.00 \\
\hline & $2 \mathrm{mM}$ VPA $72 \mathrm{~h}$ & 1.92 & $53.70^{\mathrm{b}}$ & $43.52^{\mathrm{a}}$ & 81.31 & 100.00 \\
\hline & $1 \mathrm{mM}$ VPA 14 days & $0.00^{\mathrm{a}}$ & $0.00^{\mathrm{c}}$ & $99.21^{\mathrm{c}}$ & $100.00^{c}$ & 100.00 \\
\hline & $1 \mathrm{mM}$ VPA 30 days & $0.00^{\mathrm{a}}$ & $0.00^{\mathrm{c}}$ & $0.00^{\mathrm{c}}$ & $0.00^{\mathrm{c}}$ & $0.00^{\mathrm{c}}$ \\
\hline & RPMI $10 \%$ FCS 14 days & $100.00^{c}$ & $54.37^{\mathrm{b}}$ & $100.00^{c}$ & $100.00^{c}$ & 100.00 \\
\hline & RPMI $10 \%$ FCS 30 days & $98.30^{\mathrm{c}}$ & 79.17 & $100.00^{c}$ & $100.00^{c}$ & 100.00 \\
\hline \multirow[t]{6}{*}{ G179 } & Untreated & 100.00 & 99.17 & 100.00 & 98.21 & 0.00 \\
\hline & $2 \mathrm{mM}$ VPA $72 \mathrm{~h}$ & 96.32 & 100.00 & 100.00 & 100.00 & 0.00 \\
\hline & 2 mM VPA 14 days & 100.00 & $73.56^{\mathrm{c}}$ & 100.00 & 100.00 & 0.00 \\
\hline & 2 mM VPA 30 days & 100.00 & $0.00^{\mathrm{c}}$ & 100.00 & 100.00 & $100.00^{c}$ \\
\hline & RPMI $10 \%$ FCS 14 days & 100.00 & 96.48 & 98.20 & 100.00 & $95.28^{c}$ \\
\hline & RPMI $10 \%$ FCS 30 days & 100.00 & 94.07 & 100.00 & 100.00 & $100.00^{c}$ \\
\hline \multirow[t]{6}{*}{ GliNS2 } & Untreated & 100.00 & 79.63 & 71.43 & 93.64 & 100.00 \\
\hline & $2 \mathrm{mM}$ VPA $72 \mathrm{~h}$ & $55.50^{\mathrm{c}}$ & 88.46 & 62.96 & 89.32 & $90.74^{\mathrm{b}}$ \\
\hline & 2 mM VPA 14 days & $28.15^{\mathrm{c}}$ & $0.00^{c}$ & 95.93 & 0.00 & $0.00^{\mathrm{c}}$ \\
\hline & 2 mM VPA 30 days & $0.00^{c}$ & $100.00^{c}$ & 100.00 & 0.00 & $0.00^{\mathrm{c}}$ \\
\hline & RPMI $10 \%$ FCS 14 days & $90.48^{\mathrm{a}}$ & $100.00^{c}$ & 100.00 & 100.00 & 100.00 \\
\hline & RPMI $10 \%$ FCS 30 days & $93.14^{\mathrm{a}}$ & $97.17^{\mathrm{b}}$ & 100.00 & 100.00 & 100.00 \\
\hline \multirow[t]{6}{*}{ GBM04 } & Untreated & 86.29 & 96.58 & 76.78 & 86.08 & 0.00 \\
\hline & $2 \mathrm{mM}$ VPA $72 \mathrm{~h}$ & $100.00^{c}$ & 97.33 & $88.28^{\mathrm{c}}$ & $44.17^{\mathrm{c}}$ & 0.00 \\
\hline & 2 mM VPA 14 days & $11.29^{\mathrm{c}}$ & $0.00^{c}$ & $54.20^{\mathrm{c}}$ & $100.00^{c}$ & $76.03^{c}$ \\
\hline & 2 mM VPA 30 days & $0.00^{c}$ & $0.00^{\mathrm{c}}$ & $0.00^{c}$ & $0.00^{c}$ & $100.00^{c}$ \\
\hline & RPMI $10 \%$ FCS 14 days & $100.00^{c}$ & 100.00 & $100.00^{c}$ & $100.00^{c}$ & $96.36^{c}$ \\
\hline & RPMI $10 \%$ FCS 30 days & $100.00^{c}$ & 100.00 & $100.00^{c}$ & 88.24 & $100.00^{c}$ \\
\hline
\end{tabular}

Expression of markers was evaluated in untreated and valproic acid (VPA)-treated cells for 14 and 30 days. The table also shows data derived following a 72-h VPA treatment as previously described by our group (25); all the other data are original. Cells cultured in RPMI supplemented with $10 \%$ FCS were considered as a positive control of differentiation. Fisher's exact test was used for statistical analysis (treated vs. untreated cells). ${ }^{\mathrm{P}}<0.05$; ${ }^{\mathrm{b}} \mathrm{P}<0.001 ;{ }^{\mathrm{c}} \mathrm{P}<0.0001$.

DNA Immunoprecipitation protocol (version 1.0; Agilent Technologies, Santa Clara, CA, USA).

The raw data, expressed as combined z-score values, were analyzed according to the methodological approach conceived by Dr Ravid Straussman (27). This method allowed us to classify the methylation status of each CpG island (CGI) as methylated, unmethylated, or undetermined (CGIs with uncertain methylation status). Then, we decided to consider only data referred to CGIs located in gene promoters for the subsequent analysis due to the well-known biological effects of methylation in these regions. When a promoter contained two or more CGIs, we averaged the related combined z-score values in order to establish the correct methylation status. Finally, we compared data from the untreated and VPA-treated samples to highlight the methylation changing promoters. 


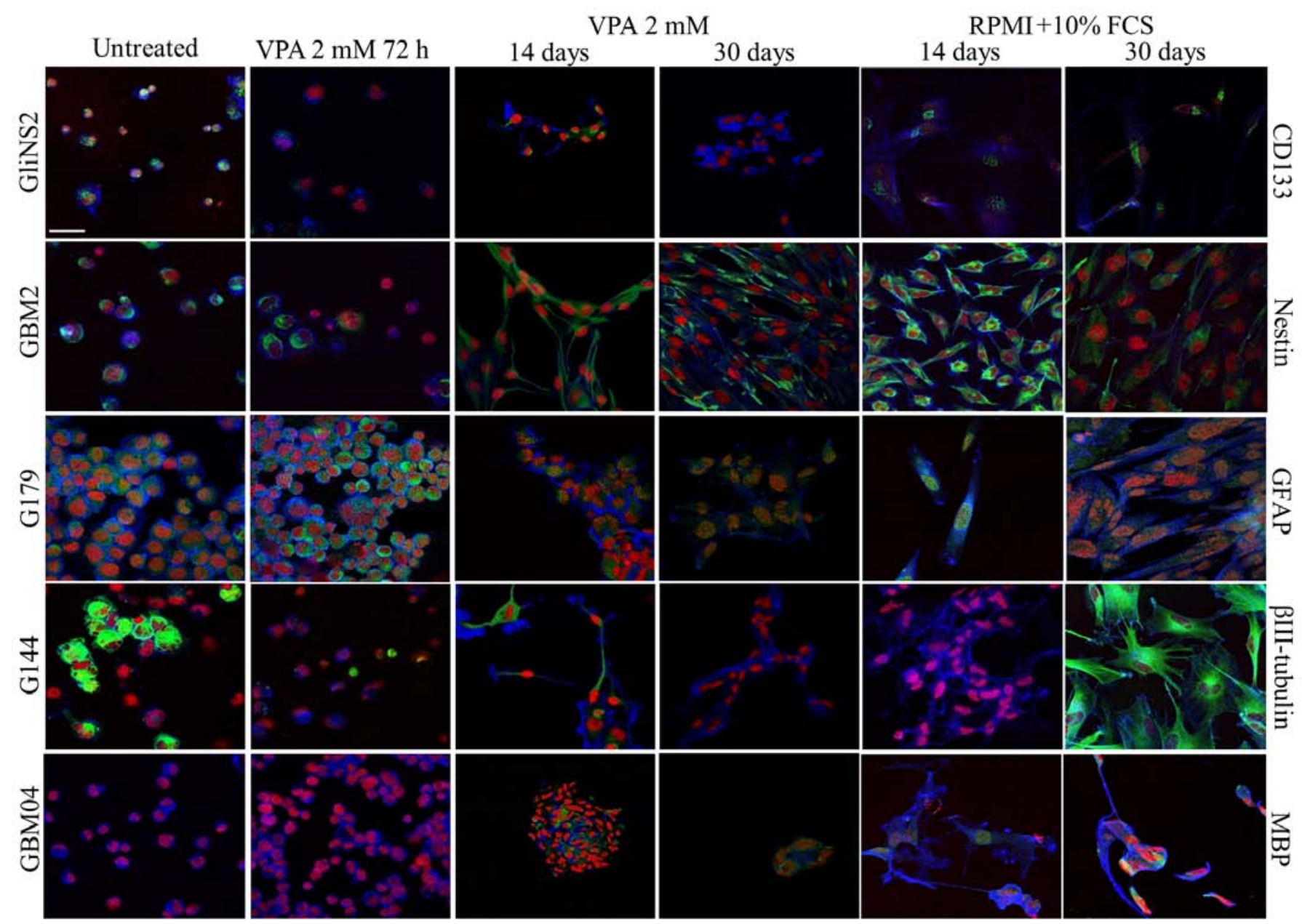

Figure 2. Representative images of the immunofluorescence analysis performed on untreated glioma stem cells (GSCs) and GSCs treated for 14 and 30 days with $2 \mathrm{mM}$ valproic acid (VPA). Cells cultured for 14 and 30 days in 10\% FBS RPMI medium represent a positive control of the differentiation capability. Cells were immunostained with antibodies against stemness (CD133, Nestin) and differentiation (GFAP, BIII tubulin, MBP) markers (green), phalloidin (blue) and propidium iodide (red). Images were captured using confocal microscopy. G166 cells were treated with $1 \mathrm{mM}$ VPA. For GBM7, the prevailing cytotoxic effect of long-term VPA treatment did not allow to conduct the experiment. Scale bar, $100 \mu \mathrm{m}$.

Bioinformatic analysis. The Gene Ontology (GO) analysis was performed, as previously described (24), using GOstat software (http://gostat.wehi.edu.au/) (28).

Statistical analysis. Statistical analysis was carried out performing Fisher's exact and Student's t-tests. The critical level of significance was set at $\mathrm{P}<0.05$.

\section{Results}

Effect of short- and long-term VPA treatments on GSC morphology. In a previous study, we evaluated the effect on GSC morphology induced by VPA after 24,48 and $72 \mathrm{~h}$ (25). We revealed that short-term VPA treatment severely modified cell morphology. In this study, we extended the evaluation to 14 and 30 days of treatment.

After 14 and, particularly, 30 days of exposure, the pro-differentiating effect of VPA was evident: most of the cells were star-shaped and displayed neurite-like processes (Fig. 1). G166 and GBM7 cells showed a high number of dead cells, demonstrating the predominant cytotoxic effect of VPA or the induction of apoptosis following terminal differentiation. Therefore, these two cell lines were treated with a lower drug concentration $(1 \mathrm{mM})$ for 14 and 30 days. While G166 cells showed important morphological modifications at this lower concentration treatment, the GBM7 cell line was still extremely sensitive, showing a prevalence of cell death.

Differentiation behavior of GSCs in response to short- and long-term VPA treatment. The pro-differentiation ability of VPA was evaluated analyzing the expression of markers of stemness (CD133 and Nestin) and differentiation (GFAP, $\beta$ III-tubulin and MBP) by immunofluorescence in the untreated and $2 \mathrm{mM}$ VPA-treated cells for 14 and 30 days. We compared these data with those we had obtained after VPA short-term treatment (25).

The summary of the immunofluorescence results is reported in Table I, and representative images are shown in Fig. 2. After 14 and 30 days of VPA exposure, 100\% of the GBM2 cells maintained nestin, $\beta$ III-tubulin and GFAP expression. Regarding CD133 and MBP markers, we observed a significant increase in cells expressing these two proteins with the prolongation of the treatment time. The G144 cell line manifested a reduction in cells expressing both stemness and differentiation markers after 30 days compared to the control cells. An unusual behavior was observed for GFAP, for which 

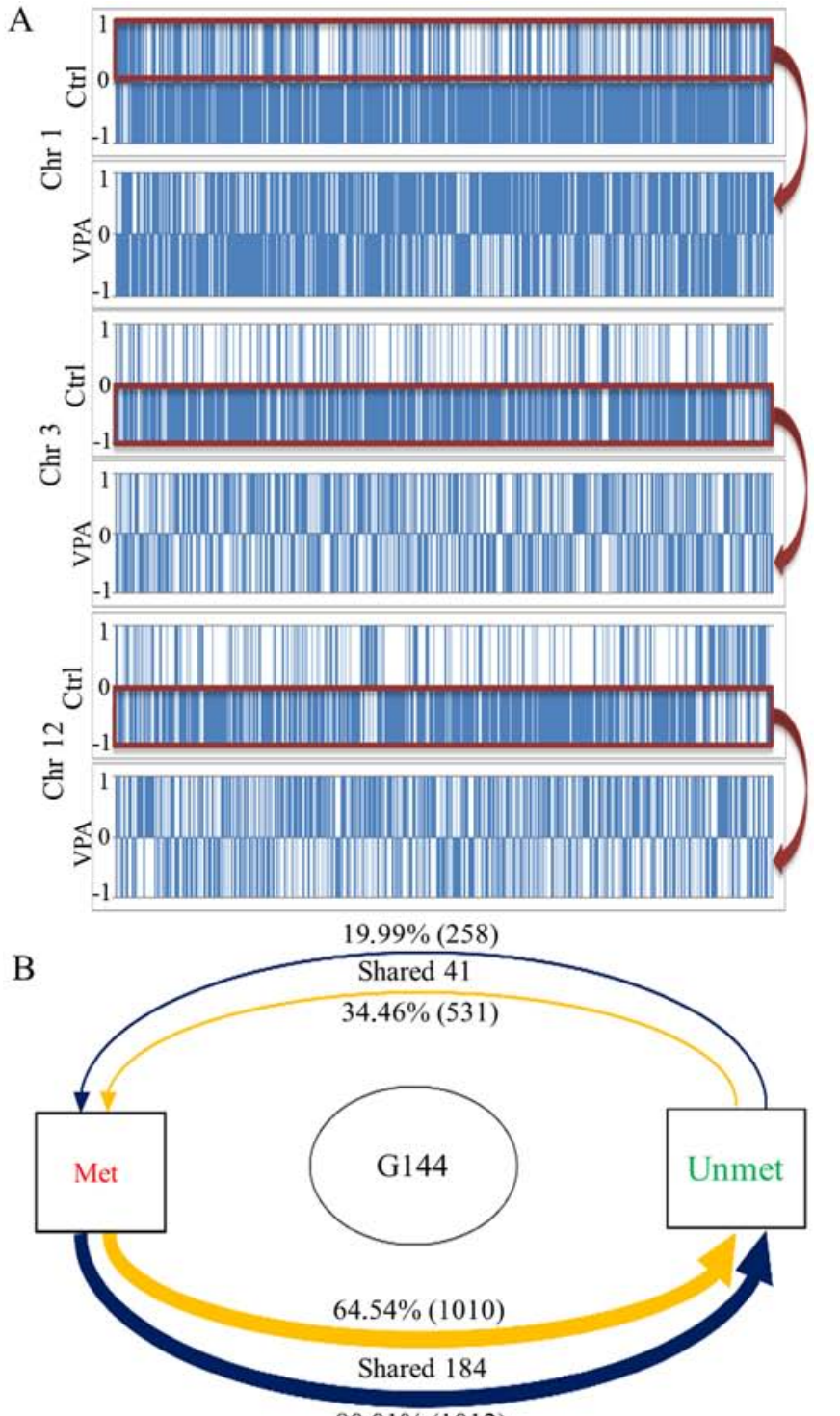

$80.01 \%(1012)$

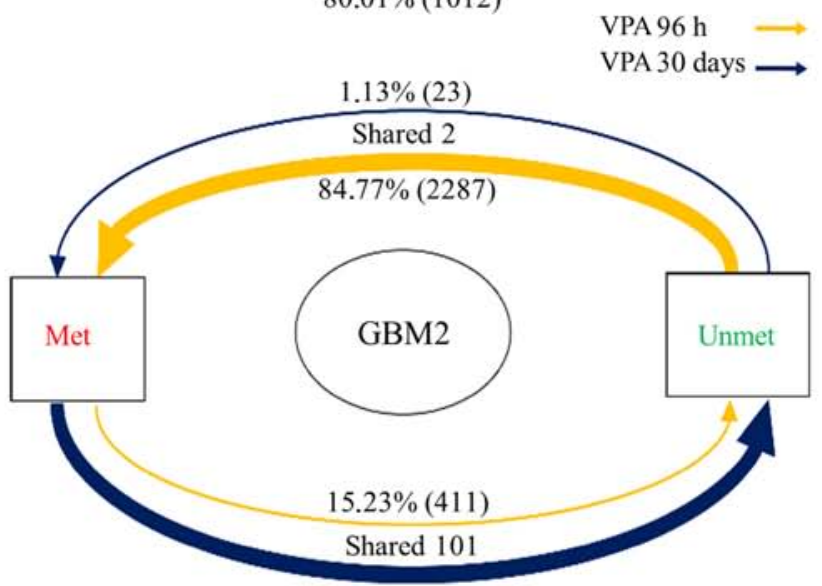

$98.87 \%(2008)$

Figure 3. (A) Methylation profile changes of chromosomes 1, 3 and 12 in glioma stem cells (GSCs) treated with $2 \mathrm{mM}$ valproic acid (VPA) for $96 \mathrm{~h}$. Each blue bar represents an oligonucleotide probe. In particular, bar 1 indicates methylated probes, while bar -1 represents unmethylated probes. These raw data, taken as examples, show that VPA treatment induced serious changes in the CGI methylation status. (B) Percentages of modified methylation status promoters in CTRL vs. VPA $96 \mathrm{~h}$ and CTRL vs. VPA 30 days. Yellow and blue arrows represent the percentages of modified methylation gene promoters (Unmet $\rightarrow$ Met; Met $\rightarrow$ Unmet) following VPA treatments for $96 \mathrm{~h}$ and 30 days, respectively. Note the different behaviors of the two GSC lines at $96 \mathrm{~h}$ of VPA and, instead, a similar trend at 30 days of VPA. there was a decrease in cells expressing GFAP after 14 days, while this number increased after 30 days, but remained significantly below the untreated control. The G166 cell line showed a very high number of cells expressing differentiation markers after 14 days of treatment; after 30 days these values were drastically decreased. In contrast, few cells were positive for both Nestin and CD133 after 14 days of treatment. The GliNS2 cell line showed a significant reduction in CD133, GFAP and MBP immunoreactive cells after 14 and 30 days of treatment. Contrariwise, the percentage of cells positive for $\beta$ III-tubulin was increased after both treatment times. An unusual behavior was observed for Nestin as after 14 days almost all cells were negative, while after 30 days nearly all cells were positive. After 30 days, the GBM04 cell line exhibited an enrichment of cells expressing MBP, probably indicating the capability to induce oligodendrocyte differentiation, while all other markers were negative. Almost 100\% of G179 cells retained the expression of CD133, $\beta$ III-tubulin and GFAP after 14 and 30 days. The longest treatment caused a significant decrease in cells expressing Nestin; in contrast, a strong increase in cells expressing MBP was observed after this specific time.

In our previous study (25), we showed that GSCs expressed both stemness and differentiation markers at variable levels in untreated and $72 \mathrm{~h}$ VPA-treated samples. This behavior persisted also after VPA long-term treatments in 3 out of 6 cell lines (GBM2, G179 and GliNS2). Notably, the others did not show immunoreactive cells for stemness markers after 30 days of treatment.

Methylation profiles of GSCs after short- and long-term VPA treatments. We investigated the effect of $2 \mathrm{mM}$ VPA administration for $96 \mathrm{~h}$ and 30 days on the CGI methylation status of two GSC lines characterized by a different susceptibility to this drug. In particular, the GBM2 cell line showed a reduced viability after a $72 \mathrm{~h}$ VPA treatment and co-expressed stemness and differentiation markers also after 30 days of VPA exposure, while the G144 cell line did not display any reduction in cell viability, but it seemed able to differentiate terminally after long-term VPA exposure.

Following observation of the raw data of the three chromosomes taken as examples (Fig. 3A), it is clear that VPA severely affected CGIs within the gene promoters. The results of the two treatments were matched with the respective untreated control cells at $96 \mathrm{~h}$ and 30 days of culture in order to normalize the spontaneous fluctuations of the methylation status due to in vitro expansion, and finally the two regimens were compared to each other.

We calculated the percentage of genes that did not change their methylation status after treatment (Table II, 'unchanged' columns), and the percentage of genes that, instead, had a modified methylation status after the regimen (Table II, 'modified' columns).

The two cell lines did not show substantial differences between each other in the 'unchanged' category, in which the class of unmethylated genes was the most highly represented. Instead, in the 'modified' category they behaved somewhat differently: in the GBM2 cell line a high percentage of genes switched from an unmethylated to a methylated status after $96 \mathrm{~h}(23.27 \%)$, while a similar percentage of genes moved in the opposite direction after 30 days $(21.73 \%)$. Conversely, in the 
Table II. Percentages of gene promoters with unchanged or modified methylation status in CTRL vs. VPA 96 h, CTRL vs. VPA 30 days and VPA $96 \mathrm{~h}$ vs. VPA 30 day comparisons.

\begin{tabular}{|c|c|c|c|c|c|c|c|}
\hline \multirow[b]{2}{*}{ Cell line } & \multirow[b]{2}{*}{ Comparisons } & \multicolumn{3}{|c|}{$\begin{array}{l}\text { Unchanged methylation status } \\
\text { promoters }(\%)\end{array}$} & \multicolumn{3}{|c|}{$\begin{array}{l}\text { Modified methylation status } \\
\text { promoters }(\%)\end{array}$} \\
\hline & & Methylated & Unmethylated & $\begin{array}{c}\text { Total } \\
\text { unchanged }\end{array}$ & Met $\rightarrow$ Unmet & Unmet $\rightarrow$ Met & $\begin{array}{c}\text { Total } \\
\text { modified }\end{array}$ \\
\hline \multirow[t]{3}{*}{ G144 } & CTRL vs. VPA $96 \mathrm{~h}$ & 17.96 & 64.56 & 82.52 & 11.82 & 5.66 & 17.48 \\
\hline & CTRL vs. VPA 30 days & 24.76 & 60.48 & 85.24 & 11.81 & 2.95 & 14.76 \\
\hline & VPA 96 h vs. VPA 30 days & 13.91 & 63.88 & 77.79 & 9.59 & 12.62 & 22.21 \\
\hline \multirow[t]{3}{*}{ GBM2 } & CTRL vs. VPA $96 \mathrm{~h}$ & 16.93 & 54.60 & 71.53 & 5.20 & 23.27 & 28.47 \\
\hline & CTRL vs. VPA 30 days & 14.94 & 63.07 & 78.01 & 21.73 & 0.26 & 21.99 \\
\hline & VPA 96 h vs. VPA 30 days & 10.38 & 54.99 & 65.37 & 29.95 & 4.68 & 34.63 \\
\hline
\end{tabular}

The 'Methylated' and 'Unmethylated' columns represent the percentages of gene promoters that maintained, respectively, the methylated or unmethylated status. The 'Met $\rightarrow$ Unmet' and 'Unmet $\rightarrow$ Met' columns show the percentages of gene promoters with modified methylation status, respectively, from methylated to unmethylated and vice versa. VPA, valproic acid.

G144 cell line VPA produced a comparable change in regards to both short- and long-term treatments, since an analogous percentage of genes was found in both directions (11.82 and $5.66 \%$ after 96 h, 11.81 and $2.95 \%$ after 30 days). These data can also be appreciated by comparing the two regimens with each other directly. Indeed, the percentages of the 'modified' category were similar in the G144 cell line (9.59 and 12.62\%), reflecting the homogeneity of both short- and long-term VPA treatments (Table II, row 3). On the contrary, in the GBM2 cell line the percentage of the 'modified' category $96 \mathrm{~h}$ versus 30 days was very different (29.95 vs. $4.68 \%$ ) (Table II, row 6).

In order to evaluate the methylation changes specifically caused by VPA treatment and not by fluctuations due to in vitro expansion, we chose the genes that showed a change in the same direction following both treatments, thus assuming that the changes occurred during the short-term treatment and were maintained until the second time-point, i.e., the change was stable. Judging from the fraction of the genes with modified methylation status that were shared at the two treatment times, the changes made by VPA in the G144 cell line, although less relevant, appeared more stable and maintained than those recorded in the GBM2 cell line, where few genes retained the same methylation profile in the two treatments (Fig. 3B). Indeed, a large fraction of genes changed from unmethylated to methylated status after $96 \mathrm{~h}$ of VPA, but after 30 days of VPA a similar number of genes returned back from a methylated to an unmethylated status (Fig. 3B). With regard to the G144 cell line, we observed that the majority of "modified' genes underwent a variation of the methylation pattern from methylated to unmethylated status in both treatments. These behaviors could be assessed to the different initial VPA sensitivities of the two cell lines and to a sort of resistance mechanism acquired during long-term VPA treatment by the GBM2 cell line.

Gene Ontology analysis revealed that two functional categories were more represented after short- and long-term VPA treatments in both cell lines: 'development and differentiation' and 'metabolism' (Fig. 4). Interestingly, VPA treatments induced in both cell lines a general trend to the unmethylated status for the 'neural differentiation and nervous system process' category. Once again, the G144 and GBM2 cell lines showed differences related to the effect of long-term treatment. Indeed, in the GBM2 cell line the gene list of the 'switched from unmethylated to methylated status' did not show any statistically significant GO terms after longterm treatment (Fig. 4).

Finally, we investigated whether the short- and long-term treatments influence the methylation status of specific genes involved in critical signaling pathways responsible for GBM initiation, migration and invasion, such as WNT, SHH, PDGFR and EGFR pathways (29,30). First of all, following analysis of the methylation status of several critical genes in the two untreated cell lines, we observed, for example in the $96 \mathrm{~h}$ controls, that they showed several homologies such as the unmethylated status of many tumor-suppressor genes (TSC1, NF2, SMAD4 and MEN1, EXT1, GPC3 and RB1), but for other genes the results were discrepant. For example, PTEN and E-cadherin (CDH1) were methylated in the GBM2 cell line and unmethylated in the G144 cell line, while CTNNB1, several WNT ligands and RUNX1 were methylated in G144 and unmethylated in GBM2 (Table III).

In the second instance, we considered the methylation status of the same genes after the drug treatments. The general effect attributable to VPA in both cell lines was towards an unmethylated status of the genes in all pathways considered. Furthermore, a greater number of genes showed this switch (from methylated to unmethylated status) after 30 days of VPA treatment, compared to $96 \mathrm{~h}$ (Table III).

VPA resistance in VPA long-term treated cells. To confirm the hypothesis of the acquisition of a resistant phenotype after VPA long-term treatment by the GBM2 cell line, we performed analysis of the cell viability by MTT assay on naïve and VPA-pretreated G144 and GBM2 cells.

The results showed that G144 cell viability after VPA treatment was generally not modified by the pretreatment for 

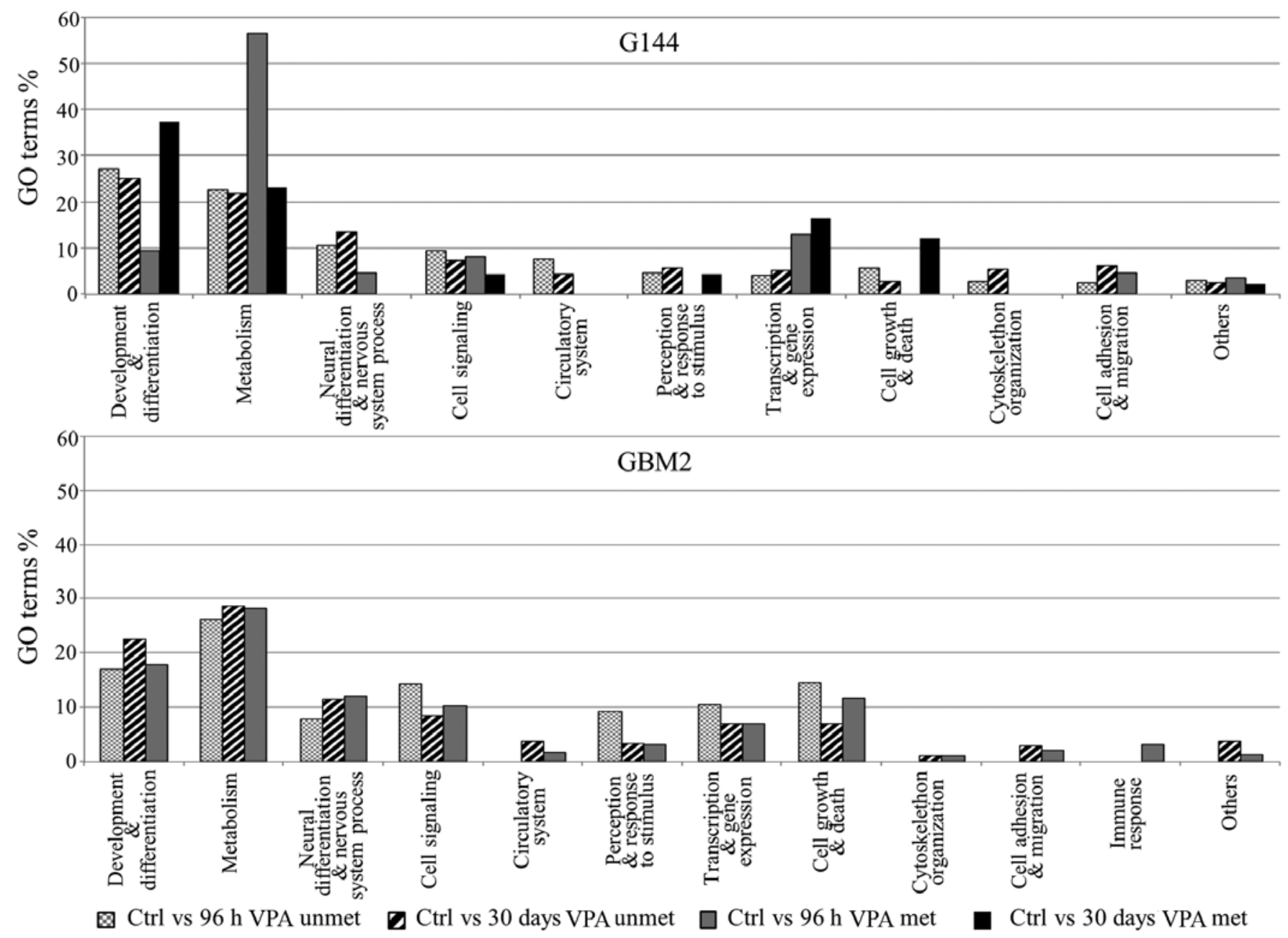

Figure 4. Gene functional groups with valproic acid (VPA)-influenced DNA methylation status after short- and long-term treatments. The functional annotation analysis of genes with modified methylation status after short- and long-term VPA treatments was performed using the GOstat software. The statistically significant GO terms obtained from the Gene Ontology analysis were grouped in cancer relevant categories. In the graph, we show a percentage related to each category. This value is the ratio between the GO term number of a specific category and the totality of the statistically significant GO terms.

30 days, as expected. In fact, this cell line was already resistant, as confirmed by the low VPA sensitivity of naïve cells (Fig. 5A).

With regard to the GBM2 cell line, we already observed a consistent cell viability reduction in the naïve cells, especially at 48 and $72 \mathrm{~h}$ of treatment (65 and 62\%, respectively). VPA long-term pretreated GBM2 cells showed a reduced sensitivity to the drug when compared to the naïve GBM2 cells at all the time-points tested; the induction of a resistant phenotype in the GBM2 cell line, probably due to the long-term in vitro exposure to $2 \mathrm{mM}$ VPA, was particularly evident at $48 \mathrm{~h}$ of treatment in which the cell viability of the 30 day-exposed cells reached $92 \%(\mathrm{P}<0.0001)$ (Fig. 5A).

VPA treatment failed to sensitize GSCs to TMZ. In GBM, first-line treatment includes radical surgical resection followed by concurrent radiotherapy and chemotherapy, typically temozolomide (TMZ) (31). TMZ exerts cytotoxicity against GBM cells by creating $\mathrm{O}^{6}$-methylguanine lesions, which leads to DNA fragmentation (32). The response to $\mathrm{TMZ}$ is favorably affected by the promoter methylation of the methylguanine-DNA methyltransferase (MGMT) gene. This enzyme removes, if expressed, the methyl groups added by TMZ, thereby preventing GBM cell death (33). In this study we evidenced that, in GBM2 cells, the MGMT promoter switched from an unmethylated to a methylated status after $96 \mathrm{~h}$ of VPA treatment (Table III). To verify whether VPA treatment was able to increase TMZ efficacy by virtue of this change in MGMT promoter methylation, we analyzed cell viability after $2 \mathrm{mM}$ VPA (96 h) plus several doses of TMZ (48 h). Unexpectedly, the results showed that VPA exposure did not produced any relevant increase in TMZ efficacy in the GBM2 cell line. In fact, cell viability was reduced at all drug combinations in a statistically significant manner when compared to TMZ only treatments (except for VPA plus $400 \mu \mathrm{M}$ TMZ), but no statistically significant difference was observed with the VPA single treatment $(\mathrm{P}>0.05)$ (Fig. 5B). Furthermore, CI values for the combined treatments clearly indicated the presence of antagonism between the two compounds (CI>1; Table IV).

The MGMT promoter in the G144 cell line was methylated and this status was not altered by VPA; this cell line could be virtually sensitive to TMZ. Surprisingly, the G144 cells were resistant to TMZ and this issue was not modified by VPA treatment, suggesting the presence of a complex pattern of drug resistance mechanisms (CI>1; Table IV) (Fig. 5B). 
Table III. Changes in the methylation status of genes involved in several glioma-related pathways, in neural differentiation and in stemness maintenance after short- and long-term VPA treatment.

\begin{tabular}{|c|c|c|c|c|}
\hline \multirow[b]{3}{*}{ Pathway/genes } & \multicolumn{2}{|c|}{ G144 } & \multicolumn{2}{|c|}{ GBM2 } \\
\hline & $96 \mathrm{~h}$ & 30 days & $96 \mathrm{~h}$ & 30 days \\
\hline & $\mathrm{Ctrl} \rightarrow \mathrm{VPA}$ & $\mathrm{Ctrl} \rightarrow \mathrm{VPA}$ & $\mathrm{Ctrl} \rightarrow \mathrm{VPA}$ & $\mathrm{Ctrl} \rightarrow \mathrm{VPA}$ \\
\hline
\end{tabular}

Receptor tyrosine kinase pathway

\begin{tabular}{|c|c|c|c|c|c|c|c|c|c|}
\hline \multirow{3}{*}{\multicolumn{5}{|c|}{$\begin{array}{l}\text { in several glioma-related pathways, in neural differentiation } \\
\text { and in stemness maintenance after short- and long-term VPA } \\
\text { treatment. }\end{array}$}} & \multirow{2}{*}{\multicolumn{3}{|c|}{ G144 }} & \multirow{2}{*}{\multicolumn{2}{|c|}{ GBM2 }} \\
\hline & & & & & & & & & \\
\hline & & & & & \multirow[b]{2}{*}{ Pathway/genes } & & 30 days & $96 \mathrm{~h}$ & 30 days \\
\hline \multirow[b]{3}{*}{ Pathway/genes } & \multicolumn{2}{|c|}{ G144 } & \multicolumn{2}{|c|}{ GBM2 } & & $\mathrm{Ctrl} \rightarrow \mathrm{VPA}$ & $\mathrm{Ctrl} \rightarrow \mathrm{VPA}$ & $\mathrm{Ctrl} \rightarrow \mathrm{VPA}$ & $\mathrm{Ctrl} \rightarrow \mathrm{VPA}$ \\
\hline & $96 \mathrm{~h}$ & 30 days & $96 \mathrm{~h}$ & 30 days & \multicolumn{5}{|l|}{ p53 pathway } \\
\hline & $\mathrm{Ctrl} \rightarrow \mathrm{VPA}$ & $\mathrm{Ctrl} \rightarrow \mathrm{VPA}$ & $\mathrm{Ctrl} \rightarrow \mathrm{VPA}$ & $\mathrm{Ctrl} \rightarrow \mathrm{VPA}$ & TP53I3 & $\mathrm{U}$ & $\mathrm{U} \rightarrow \mathrm{M}$ & $\mathrm{U}$ & $\mathrm{M} \rightarrow \mathrm{U}$ \\
\hline \multirow{2}{*}{\multicolumn{5}{|c|}{ Receptor tyrosine kinase pathway }} & TP53INP1 & M & M & M & $\mathrm{M} \rightarrow \mathrm{ND}$ \\
\hline & & & & & $\begin{array}{l}\text { TP53I11 } \\
\text { TP53INP? }\end{array}$ & U & M & $\begin{array}{l}\mathrm{U} \rightarrow \mathrm{M} \\
\mathrm{M} \rightarrow \mathrm{U}\end{array}$ & $\begin{array}{l}M \rightarrow U \\
M \rightarrow U\end{array}$ \\
\hline $\begin{array}{l}\text { ALK } \\
\text { EGFR }\end{array}$ & $\begin{array}{l}\mathrm{U} \\
\mathrm{U}\end{array}$ & $\mathrm{M} \rightarrow \mathrm{U}$ & $\mathrm{ND} \rightarrow \mathrm{U}$ & $\begin{array}{l}\mathrm{U} \\
\mathrm{U}\end{array}$ & $\begin{array}{l}\text { TP53INP2 } \\
\text { MDM2 }\end{array}$ & $\stackrel{\mathrm{M} \rightarrow \mathrm{ND}}{\mathrm{U}}$ & $\begin{array}{l}\text { U } \\
M\end{array}$ & $\begin{array}{l}M \rightarrow U \\
M \rightarrow U\end{array}$ & $\begin{array}{c}\mathrm{M} \rightarrow \mathrm{U} \\
\mathrm{U}\end{array}$ \\
\hline PDGFRL & $\mathrm{U}$ & $\mathrm{U}$ & $\mathrm{U}$ & $\mathrm{U}$ & NOTCH1 & $\mathrm{U}$ & $\mathrm{U}$ & $\mathrm{U}$ & $\mathrm{U}$ \\
\hline PDGFC & $\mathrm{U} \rightarrow \mathrm{ND}$ & $\mathrm{M} \rightarrow \mathrm{U}$ & $\mathrm{U}$ & $\mathrm{U}$ & PUMA & $\mathrm{M} \rightarrow \mathrm{U}$ & $\mathrm{U} \rightarrow \mathrm{M}$ & $\mathrm{U}$ & $\mathrm{M} \rightarrow \mathrm{U}$ \\
\hline PDGFD & $\mathrm{M} \rightarrow \mathrm{U}$ & $\mathrm{U}$ & $\mathrm{U} \rightarrow \mathrm{M}$ & $\mathrm{M} \rightarrow \mathrm{U}$ & NOXA & M & M & $\mathrm{U}$ & $\mathrm{U}$ \\
\hline PDGFB & $\mathrm{U}$ & $\mathrm{M} \rightarrow \mathrm{U}$ & $\mathrm{U}$ & $\mathrm{M} \rightarrow \mathrm{U}$ & BCL2 & $\mathrm{U}$ & $\mathrm{M} \rightarrow \mathrm{U}$ & ND & $\mathrm{M} \rightarrow \mathrm{U}$ \\
\hline SHC1 & $\mathrm{U}$ & $\mathrm{U}$ & $\mathrm{U}$ & $\mathrm{U}$ & BAX & $\mathrm{U}$ & $\mathrm{M} \rightarrow \mathrm{U}$ & $\mathrm{U}$ & $\mathrm{U}$ \\
\hline SHC2 & $\mathrm{M} \rightarrow \mathrm{U}$ & M & $\mathrm{U} \rightarrow \mathrm{ND}$ & $\mathrm{M} \rightarrow \mathrm{U}$ & $\mathrm{P} 21$ & $\mathrm{U}$ & $\mathrm{U}$ & $\mathrm{U}$ & $\mathrm{U}$ \\
\hline SHC3 & $\mathrm{U}$ & $\mathrm{U}$ & $\mathrm{U}$ & $\mathrm{U}$ & CDK6 & $\mathrm{U}$ & $\mathrm{U}$ & $\mathrm{U}$ & $\mathrm{U}$ \\
\hline SHC4 & $\mathrm{U}$ & $\mathrm{U}$ & $\mathrm{U}$ & $\mathrm{U}$ & CDK7 & $\mathrm{U}$ & $\mathrm{U}$ & $\mathrm{U}$ & $\mathrm{U}$ \\
\hline GRB2 & $\mathrm{U}$ & $\mathrm{U}$ & $\mathrm{U}$ & $\mathrm{U}$ & CDK8 & $\mathrm{M} \rightarrow \mathrm{U}$ & $\mathrm{U}$ & $\mathrm{U}$ & $\mathrm{U}$ \\
\hline SOS1 & $\mathrm{U}$ & $\mathrm{U}$ & $\mathrm{U}$ & $\mathrm{U}$ & CDK10 & $\mathrm{U}$ & $\mathrm{U}$ & $\mathrm{U}$ & $\mathrm{U}$ \\
\hline SOS2 & $\mathrm{U}$ & $\mathrm{U}$ & $\mathrm{U}$ & $\mathrm{U}$ & CCND1 & $\mathrm{M} \rightarrow \mathrm{ND}$ & M & $\mathrm{ND} \rightarrow \mathrm{M}$ & $\mathrm{M} \rightarrow \mathrm{ND}$ \\
\hline RAS & $\mathrm{U}$ & $\mathrm{M} \rightarrow \mathrm{U}$ & $\mathrm{U}$ & $\mathrm{U}$ & MSH2 & $\mathrm{U}$ & $\mathrm{M} \rightarrow \mathrm{U}$ & $\mathrm{M} \rightarrow \mathrm{U}$ & $\mathrm{M} \rightarrow \mathrm{U}$ \\
\hline RAF & $\mathrm{U}$ & $\mathrm{U}$ & $\mathrm{U}$ & $\mathrm{M} \rightarrow \mathrm{U}$ & BRCA1 & $\mathrm{U}$ & $\mathrm{U}$ & $\mathrm{M}$ & $\mathrm{M}$ \\
\hline MAP2K1 & $\mathrm{U}$ & $\mathrm{U} \rightarrow \mathrm{M}$ & $\mathrm{U}$ & $\mathrm{U}$ & \multicolumn{5}{|c|}{ PI3K/AKT pathway } \\
\hline MAP2K2 & $\mathrm{U}$ & $\mathrm{M} \rightarrow \mathrm{ND}$ & $\mathrm{U}$ & $\mathrm{U}$ & PDK2 & $\mathrm{U} \rightarrow \mathrm{ND}$ & $\mathrm{U}$ & $\mathrm{U}$ & $\mathrm{U}$ \\
\hline MAP2K3 & $\mathrm{U}$ & $\mathrm{U}$ & $\mathrm{U}$ & $\mathrm{U}$ & PTEN & $\mathrm{U}$ & $\mathrm{U}$ & M & M \\
\hline MAP2K4 & $\mathrm{U}$ & $\mathrm{U}$ & $\mathrm{U}$ & $\mathrm{U}$ & PIK3R1 & $\mathrm{U}$ & $\mathrm{U}$ & $\mathrm{U} \rightarrow \mathrm{M}$ & $\mathrm{M}$ \\
\hline MAP2K5 & $\mathrm{U}$ & $\mathrm{U}$ & $\mathrm{U}$ & U & PIK3R2 & $\mathrm{U} \rightarrow \mathrm{M}$ & $\mathrm{U}$ & $\mathrm{U}$ & $\mathrm{U}$ \\
\hline MAP2K7 & $\mathrm{U}$ & $\mathrm{U}$ & $\mathrm{U}$ & $\mathrm{M} \rightarrow \mathrm{U}$ & PIK3R3 & $\mathrm{U}$ & $\mathrm{M} \rightarrow \mathrm{U}$ & $\mathrm{U}$ & $\mathrm{U}$ \\
\hline MAPK1 & $\mathrm{M} \rightarrow \mathrm{U}$ & $\mathrm{U}$ & $\mathrm{U}$ & U & PIK3R4 & $\mathrm{U}$ & $\mathrm{U}$ & $\mathrm{ND} \rightarrow \mathrm{U}$ & $\mathrm{U}$ \\
\hline NF1 & $\mathrm{U}$ & $\mathrm{M} \rightarrow \mathrm{U}$ & $\mathrm{U}$ & $\mathrm{U}$ & PIK3CA & $\mathrm{M} \rightarrow \mathrm{U}$ & $\mathrm{U}$ & $\mathrm{U}$ & $\mathrm{U}$ \\
\hline ABL1 & $\mathrm{U}$ & $\mathrm{U}$ & $\mathrm{U}$ & $\mathrm{U}$ & PIK3C2B & $\mathrm{U}$ & $\mathrm{U}$ & $\mathrm{U}$ & $\mathrm{U}$ \\
\hline ABL2 & $\mathrm{U}$ & $\mathrm{U} \rightarrow \mathrm{M}$ & $\mathrm{U}$ & $\mathrm{U}$ & PIK3CD & $\mathrm{U}$ & $\mathrm{U}$ & $\mathrm{U}$ & $\mathrm{U}$ \\
\hline FES & $\mathrm{U}$ & M & $\mathrm{U} \rightarrow \mathrm{M}$ & M & AKT1 & $\mathrm{U}$ & $\mathrm{U}$ & $\mathrm{U} \rightarrow \mathrm{M}$ & $\mathrm{M} \rightarrow \mathrm{U}$ \\
\hline JAK1 & $\mathrm{U}$ & $\mathrm{U}$ & U & U & AKT3 & $\mathrm{U}$ & $\mathrm{U}$ & $\mathrm{U}$ & $\mathrm{U}$ \\
\hline JAK2 & $\mathrm{U}$ & $\mathrm{U}$ & $\mathrm{ND} \rightarrow \mathrm{U}$ & $\mathrm{M} \rightarrow \mathrm{U}$ & BCL2 & $\mathrm{U}$ & $\mathrm{M} \rightarrow \mathrm{U}$ & ND & $\mathrm{M} \rightarrow \mathrm{U}$ \\
\hline JAK3 & $\mathrm{M} \rightarrow \mathrm{U}$ & M & M & M & FOXO1 & $\mathrm{U}$ & $\mathrm{U}$ & $\mathrm{U}$ & $\mathrm{U}$ \\
\hline STAT1 & $\mathrm{U}$ & $\mathrm{U}$ & $\mathrm{U}$ & $\mathrm{U}$ & FOXO3 & $\mathrm{U}$ & $\mathrm{U} \rightarrow \mathrm{M}$ & $\mathrm{U}$ & $\mathrm{U}$ \\
\hline STAT2 & $\mathrm{U} \rightarrow \mathrm{M}$ & $\mathrm{U}$ & $\mathrm{U}$ & U & FOXO4 & $\mathrm{U}$ & $\mathrm{U}$ & $\mathrm{U}$ & $\mathrm{M} \rightarrow \mathrm{U}$ \\
\hline STAT3 & $\mathrm{U}$ & $\mathrm{U}$ & $\mathrm{U}$ & $\mathrm{U}$ & TSC1 & $\mathrm{U}$ & $\mathrm{M} \rightarrow \mathrm{U}$ & $\mathrm{U}$ & $\mathrm{U}$ \\
\hline RB pathway & & & & & RHEB & $\mathrm{U}$ & $\mathrm{M} \rightarrow \mathrm{U}$ & $\mathrm{U}$ & $\mathrm{U}$ \\
\hline CDKN2A & $\mathrm{U}$ & $\mathrm{U}$ & $\mathrm{ND} \rightarrow \mathrm{M}$ & M & MTOR & $\mathrm{U}$ & $\mathrm{U}$ & $\mathrm{U}$ & $\mathrm{U}$ \\
\hline CDK6 & $\mathrm{U}$ & $\mathrm{U}$ & $\mathrm{U}$ & $\mathrm{U}$ & 4EBP1 & $\mathrm{U} \rightarrow \mathrm{M}$ & $\mathrm{U}$ & $\mathrm{U} \rightarrow \mathrm{ND}$ & $\mathrm{M} \rightarrow \mathrm{U}$ \\
\hline CCND1 & $\mathrm{M} \rightarrow \mathrm{ND}$ & M & $\mathrm{ND} \rightarrow \mathrm{M}$ & $\mathrm{M} \rightarrow \mathrm{ND}$ & RAC3 & $\mathrm{U}$ & $\mathrm{M} \rightarrow \mathrm{U}$ & $\mathrm{ND} \rightarrow \mathrm{U}$ & $\mathrm{U}$ \\
\hline RB1 & $\mathrm{U}$ & $\mathrm{U}$ & $\mathrm{U}$ & $\mathrm{U}$ & RAC1 & $\mathrm{M} \rightarrow \mathrm{U}$ & $\mathrm{M} \rightarrow \mathrm{U}$ & $\mathrm{U}$ & $\mathrm{U}$ \\
\hline $\mathrm{E} 2 \mathrm{~F} 1$ & $\mathrm{U}$ & $\mathrm{U}$ & $\mathrm{U}$ & $\mathrm{U}$ & NF2 & $\mathrm{U}$ & $\mathrm{U}$ & $\mathrm{U}$ & $\mathrm{U}$ \\
\hline $\mathrm{E} 2 \mathrm{~F} 2$ & $\mathrm{U}$ & $\mathrm{U}$ & $\mathrm{U}$ & $\mathrm{U}$ & \multicolumn{5}{|l|}{ SHH pathway } \\
\hline $\mathrm{E} 2 \mathrm{~F} 3$ & $\mathrm{U}$ & $\mathrm{U}$ & $\mathrm{U}$ & $\mathrm{U}$ & SHH & $\mathrm{U}$ & $\mathrm{U}$ & $\mathrm{U}$ & $\mathrm{U}$ \\
\hline E2F5 & $\mathrm{U} \rightarrow \mathrm{ND}$ & $\mathrm{U}$ & $\mathrm{U}$ & $\mathrm{U}$ & EXT1 & $\mathrm{U}$ & $\mathrm{U}$ & $\mathrm{U}$ & $\mathrm{U}$ \\
\hline E2F6 & $\mathrm{U} \rightarrow \mathrm{M}$ & $\mathrm{U}$ & $\mathrm{U}$ & $\mathrm{U}$ & PTCH1 & $\mathrm{U}$ & $\mathrm{U}$ & $\mathrm{U}$ & $\mathrm{U}$ \\
\hline E2F7 & $\mathrm{U}$ & $\mathrm{U}$ & U & $\mathrm{U}$ & PTCH2 & M & M & $\mathrm{M} \rightarrow \mathrm{U}$ & $\mathrm{M} \rightarrow \mathrm{U}$ \\
\hline E2F8 & $\mathrm{U}$ & M & $\mathrm{U} \rightarrow \mathrm{M}$ & M & SMO & $\mathrm{M} \rightarrow \mathrm{U}$ & $\mathrm{M} \rightarrow \mathrm{U}$ & $\mathrm{U}$ & $\mathrm{M} \rightarrow \mathrm{U}$ \\
\hline TFE3 & $\mathrm{U}$ & $\mathrm{U}$ & $\mathrm{U}$ & $\mathrm{U}$ & GLI1 & $\mathrm{U}$ & $\mathrm{U}$ & $\mathrm{U}$ & $\mathrm{U}$ \\
\hline p53 pathway & & & & & GLI3 & $\mathrm{U}$ & $\mathrm{U}$ & $\mathrm{U}$ & $\mathrm{U}$ \\
\hline TP53BP2 & $\mathrm{U}$ & $\mathrm{U}$ & $\mathrm{U}$ & $\mathrm{U}$ & GLI4 & $\mathrm{U} \rightarrow \mathrm{M}$ & $\mathrm{U}$ & $\mathrm{U}$ & $\mathrm{U}$ \\
\hline
\end{tabular}

Table III. Continued. 
Table III. Continued.

\begin{tabular}{|c|c|c|c|c|}
\hline & \multicolumn{2}{|c|}{ G144 } & \multicolumn{2}{|c|}{ GBM2 } \\
\hline Pathway/genes & $\begin{array}{c}96 \mathrm{~h} \\
\mathrm{Ctrl} \rightarrow \mathrm{VPA}\end{array}$ & $\begin{array}{c}30 \text { days } \\
\text { Ctrl } \rightarrow \text { VPA }\end{array}$ & $\begin{array}{c}96 \mathrm{~h} \\
\mathrm{Ctrl} \rightarrow \mathrm{VPA}\end{array}$ & $\begin{array}{c}30 \text { days } \\
\text { Ctrl } \rightarrow \text { VPA }\end{array}$ \\
\hline
\end{tabular}

\section{WNT pathway}

\begin{tabular}{|c|c|c|c|c|}
\hline GPC3 & $\mathrm{U} \rightarrow \mathrm{ND}$ & $\mathrm{M} \rightarrow \mathrm{U}$ & $\mathrm{U}$ & $\mathrm{U}$ \\
\hline WNT2B & $\mathrm{U} \rightarrow \mathrm{ND}$ & M & $\mathrm{U}$ & $\mathrm{ND} \rightarrow \mathrm{U}$ \\
\hline WNT9A & M & M & $\mathrm{U}$ & $\mathrm{U}$ \\
\hline WNT3A & M & M & $\mathrm{U} \rightarrow \mathrm{M}$ & M \\
\hline WNT6 & $\mathrm{M} \rightarrow \mathrm{U}$ & $\mathrm{M} \rightarrow \mathrm{U}$ & $\mathrm{U}$ & $\mathrm{M} \rightarrow \mathrm{U}$ \\
\hline WNT10A & $\mathrm{M} \rightarrow \mathrm{U}$ & M & $\mathrm{U} \rightarrow \mathrm{M}$ & M \\
\hline WNT7A & $\mathrm{U}$ & $\mathrm{U}$ & $\mathrm{U}$ & $\mathrm{U}$ \\
\hline WNT5A & $\mathrm{U}$ & $\mathrm{U}$ & $\mathrm{U}$ & $\mathrm{U}$ \\
\hline WNT2 & $\mathrm{U}$ & $\mathrm{M} \rightarrow \mathrm{U}$ & $\mathrm{U}$ & $\mathrm{M} \rightarrow \mathrm{U}$ \\
\hline WNT11 & $\mathrm{M} \rightarrow \mathrm{U}$ & $\mathrm{M} \rightarrow \mathrm{U}$ & $\mathrm{U}$ & $\mathrm{M} \rightarrow \mathrm{U}$ \\
\hline WNT3 & M & M & M & $\mathrm{M} \rightarrow \mathrm{ND}$ \\
\hline WNT9B & M & $\mathrm{M} \rightarrow \mathrm{U}$ & $\mathrm{U}$ & $\mathrm{U}$ \\
\hline FZD7 & $\mathrm{U}$ & $\mathrm{M} \rightarrow \mathrm{U}$ & $\mathrm{U}$ & $\mathrm{U}$ \\
\hline FZD5 & $\mathrm{U}$ & $\mathrm{U}$ & $\mathrm{U}$ & $\mathrm{U}$ \\
\hline FZD9 & $\mathrm{U}$ & $\mathrm{M} \rightarrow \mathrm{U}$ & M & M \\
\hline FZD1 & $\mathrm{U}$ & $\mathrm{U}$ & $\mathrm{U}$ & $\mathrm{U}$ \\
\hline FZD6 & $\mathrm{U}$ & $\mathrm{M} \rightarrow \mathrm{U}$ & $\mathrm{ND} \rightarrow \mathrm{M}$ & M \\
\hline FZD8 & $\mathrm{U}$ & $\mathrm{U}$ & $\mathrm{U}$ & $\mathrm{U}$ \\
\hline FZD4 & $\mathrm{U}$ & $\mathrm{ND} \rightarrow \mathrm{M}$ & $\mathrm{U} \rightarrow \mathrm{M}$ & $M \rightarrow N D$ \\
\hline FZD10 & M & M & M & M \\
\hline FZD2 & $\mathrm{U}$ & $\mathrm{U}$ & $\mathrm{M} \rightarrow \mathrm{U}$ & $\mathrm{M} \rightarrow \mathrm{U}$ \\
\hline LRP6 & $\mathrm{U}$ & $\mathrm{U}$ & $\mathrm{U}$ & $\mathrm{U}$ \\
\hline GSK3 $\beta$ & $\mathrm{U}$ & $\mathrm{U}$ & $\mathrm{U}$ & $\mathrm{U}$ \\
\hline$\beta$-catenin & $\mathrm{M} \rightarrow \mathrm{U}$ & $\mathrm{ND} \rightarrow \mathrm{U}$ & $\mathrm{U}$ & $\mathrm{U}$ \\
\hline APC2 & $\mathrm{M} \rightarrow \mathrm{U}$ & $\mathrm{M} \rightarrow \mathrm{U}$ & ND & $\mathrm{M} \rightarrow \mathrm{U}$ \\
\hline AXIN1 & M & M & M & M \\
\hline AXIN2 & $\mathrm{U}$ & $\mathrm{U}$ & $\mathrm{U}$ & $\mathrm{U}$ \\
\hline CDH1 & $\mathrm{U}$ & M & M & $\mathrm{M} \rightarrow \mathrm{ND}$ \\
\hline$\alpha$-catenin & $\mathrm{U}$ & $\mathrm{ND} \rightarrow \mathrm{M}$ & $\mathrm{U}$ & $\mathrm{M} \rightarrow \mathrm{U}$ \\
\hline АСТВ & $\mathrm{U}$ & $\mathrm{U}$ & $\mathrm{U}$ & $\mathrm{U}$ \\
\hline ACTG1 & M & M & $\mathrm{ND} \rightarrow \mathrm{U}$ & $\mathrm{U}$ \\
\hline ACTA1 & $\mathrm{M} \rightarrow \mathrm{U}$ & M & $\mathrm{U}$ & $\mathrm{M} \rightarrow \mathrm{U}$ \\
\hline TCF7 & M & M & M & M \\
\hline TCF12 & M & M & M & M \\
\hline TCF25 & $\mathrm{M} \rightarrow \mathrm{U}$ & $\mathrm{M} \rightarrow \mathrm{U}$ & $\mathrm{U}$ & $\mathrm{M} \rightarrow \mathrm{U}$ \\
\hline TCF4 & $\mathrm{U}$ & $\mathrm{U}$ & $\mathrm{U}$ & $\mathrm{U}$ \\
\hline TCF15 & $\mathrm{U}$ & M & $\mathrm{U}$ & $\mathrm{M} \rightarrow \mathrm{U}$ \\
\hline C-MYC & $\mathrm{U}$ & $\mathrm{U}$ & $\mathrm{U}$ & $\mathrm{U}$ \\
\hline BMP4 & $\mathrm{U}$ & M & $\mathrm{U} \rightarrow \mathrm{M}$ & $\mathrm{M} \rightarrow \mathrm{U}$ \\
\hline \multicolumn{5}{|c|}{ BMP/TGF $\beta$ pathway } \\
\hline BMP2 & $\mathrm{U}$ & $\mathrm{U}$ & $\mathrm{U}$ & $\mathrm{U}$ \\
\hline BMP3 & $\mathrm{U}$ & M & $\mathrm{U}$ & $\mathrm{M} \rightarrow \mathrm{U}$ \\
\hline BMP4 & $\mathrm{U}$ & M & $\mathrm{U} \rightarrow \mathrm{M}$ & $\mathrm{M} \rightarrow \mathrm{U}$ \\
\hline BMP6 & $\mathrm{U} \rightarrow \mathrm{ND}$ & $\mathrm{U}$ & $\mathrm{U}$ & $\mathrm{U}$ \\
\hline BMP7 & $\mathrm{M} \rightarrow \mathrm{U}$ & $\mathrm{M} \rightarrow \mathrm{U}$ & $\mathrm{ND} \rightarrow \mathrm{M}$ & $\mathrm{M} \rightarrow \mathrm{ND}$ \\
\hline BMP8A & M & M & M & $\mathrm{M} \rightarrow \mathrm{ND}$ \\
\hline BMP8B & $\mathrm{M} \rightarrow \mathrm{U}$ & M & $\mathrm{ND} \rightarrow \mathrm{U}$ & $\mathrm{M} \rightarrow \mathrm{U}$ \\
\hline TGF $\beta 1$ & M & M & $\mathrm{U} \rightarrow \mathrm{M}$ & $\mathrm{M} \rightarrow \mathrm{ND}$ \\
\hline TGF $\beta 2$ & M & $\mathrm{M} \rightarrow \mathrm{U}$ & $\mathrm{U}$ & $\mathrm{U}$ \\
\hline TGF $\beta \mathrm{R} 1$ & $\mathrm{U}$ & $\mathrm{M} \rightarrow \mathrm{U}$ & $\mathrm{ND} \rightarrow \mathrm{U}$ & $\mathrm{M} \rightarrow \mathrm{U}$ \\
\hline
\end{tabular}

Table III. Continued.

\begin{tabular}{|c|c|c|c|c|}
\hline \multirow[b]{2}{*}{ Pathway/genes } & \multicolumn{2}{|c|}{ G144 } & \multicolumn{2}{|c|}{ GBM2 } \\
\hline & $\begin{array}{c}96 \mathrm{~h} \\
\mathrm{Ctrl} \rightarrow \mathrm{VPA}\end{array}$ & $\begin{array}{c}30 \text { days } \\
\text { Ctrl } \rightarrow \text { VPA }\end{array}$ & $\begin{array}{c}96 \mathrm{~h} \\
\mathrm{Ctrl} \rightarrow \mathrm{VPA}\end{array}$ & $\begin{array}{c}30 \text { days } \\
\text { Ctrl } \rightarrow \text { VPA }\end{array}$ \\
\hline \multicolumn{5}{|c|}{ BMP/TGF $\beta$ pathway } \\
\hline TGF $\beta$ R2 & $\mathrm{U}$ & $\mathrm{U}$ & $\mathrm{M} \rightarrow \mathrm{U}$ & $\mathrm{U}$ \\
\hline SMAD2 & $\mathrm{U}$ & $\mathrm{U}$ & $\mathrm{U}$ & $\mathrm{M} \rightarrow \mathrm{U}$ \\
\hline SMAD3 & $\mathrm{U}$ & $\mathrm{U}$ & $\mathrm{U}$ & $\mathrm{U}$ \\
\hline SMAD4 & $\mathrm{U}$ & $\mathrm{U}$ & $\mathrm{U}$ & $\mathrm{U}$ \\
\hline RUNX1 & $\mathrm{M} \rightarrow \mathrm{U}$ & $\mathrm{U}$ & $\mathrm{U} \rightarrow \mathrm{M}$ & $\mathrm{M} \rightarrow \mathrm{U}$ \\
\hline MEN1 & $\mathrm{U} \rightarrow \mathrm{M}$ & M & $\mathrm{U} \rightarrow \mathrm{M}$ & $\mathrm{U}$ \\
\hline \multicolumn{5}{|c|}{ Neural differentiation } \\
\hline BMPR1B & $\mathrm{U}$ & $\mathrm{U}$ & $\mathrm{U} \rightarrow \mathrm{M}$ & $\mathrm{U}$ \\
\hline TUBB3 & $\mathrm{U}$ & $\mathrm{U}$ & $\mathrm{U}$ & $\mathrm{U}$ \\
\hline MAP2 & M & $\mathrm{U}$ & $\mathrm{U} \rightarrow \mathrm{M}$ & $\mathrm{U}$ \\
\hline OLIG1 & $\mathrm{U}$ & $\mathrm{M} \rightarrow \mathrm{U}$ & $\mathrm{U}$ & $\mathrm{U}$ \\
\hline OLIG2 & $\mathrm{M} \rightarrow \mathrm{U}$ & M & M & M \\
\hline OLIG3 & $\mathrm{M} \rightarrow \mathrm{ND}$ & M & M & $\mathrm{M} \rightarrow \mathrm{U}$ \\
\hline \multicolumn{5}{|c|}{ Stemness maintenance } \\
\hline OCT4 & M & M & $\mathrm{M} \rightarrow \mathrm{U}$ & M \\
\hline NOTCH1 & $\mathrm{U}$ & $\mathrm{U}$ & $\mathrm{U} \rightarrow \mathrm{M}$ & $\mathrm{U}$ \\
\hline CD44 & $\mathrm{U}$ & $\mathrm{ND} \rightarrow \mathrm{U}$ & $\mathrm{U} \rightarrow \mathrm{M}$ & $\mathrm{ND} \rightarrow \mathrm{U}$ \\
\hline PROM1 & $\mathrm{U}$ & $\mathrm{U}$ & $\mathrm{U} \rightarrow \mathrm{M}$ & $\mathrm{U}$ \\
\hline NES & $\mathrm{U}$ & $\mathrm{U}$ & $\mathrm{U}$ & $\mathrm{M} \rightarrow \mathrm{U}$ \\
\hline MGMT & M & M & $\mathrm{U} \rightarrow \mathrm{M}$ & $\mathrm{U}$ \\
\hline
\end{tabular}

$\mathrm{U}$, unmethylated gene promoter; $\mathrm{M}$, methylated gene promoter; ND, undetermined methylation status of the gene promoter.

Table IV. Cooperative index (CI) of VPA + TMZ combined treatments (MTT assay).

\begin{tabular}{lcccc}
\hline & \multicolumn{4}{c}{ VPA 2 mM } \\
\cline { 2 - 5 } Cooperative index & GBM2 & G144 & G166 & GBM04 \\
\hline TMZ 50 $\mu \mathrm{M}$ & 1.33 & 1.35 & 1.25 & 1.33 \\
TMZ 100 $\mu \mathrm{M}$ & 1.31 & 2.01 & 1.22 & 1.37 \\
TMZ 200 $\mu \mathrm{M}$ & 1.50 & 2.21 & 1.43 & 1.54 \\
TMZ 400 $\mu \mathrm{M}$ & 1.71 & 445.80 & 1.90 & 1.51 \\
\hline CI values <1 indicate a synergistic effect; CI values =1 indicate an \\
additive effect, while CI values >1 indicate an antagonistic effect. VPA, \\
valproic acid; TMZ, temozolomide.
\end{tabular}

Considering the heterogeneity of GBM, we extended this analysis to two additional cell lines (GBM04 and G166). In both lines, all drug combinations displayed a statistically significant reduction in cell viability compared to the single treatments (except for VPA plus $200 \mu \mathrm{M}$ TMZ in the G166 cell line), but the CI values clearly indicated that there was no synergism between the two drugs (CI>1; Table IV).

Moreover, we analyzed the percentages of live and dead cells by trypan blue dye-exclusion assay in the GBM2 and 


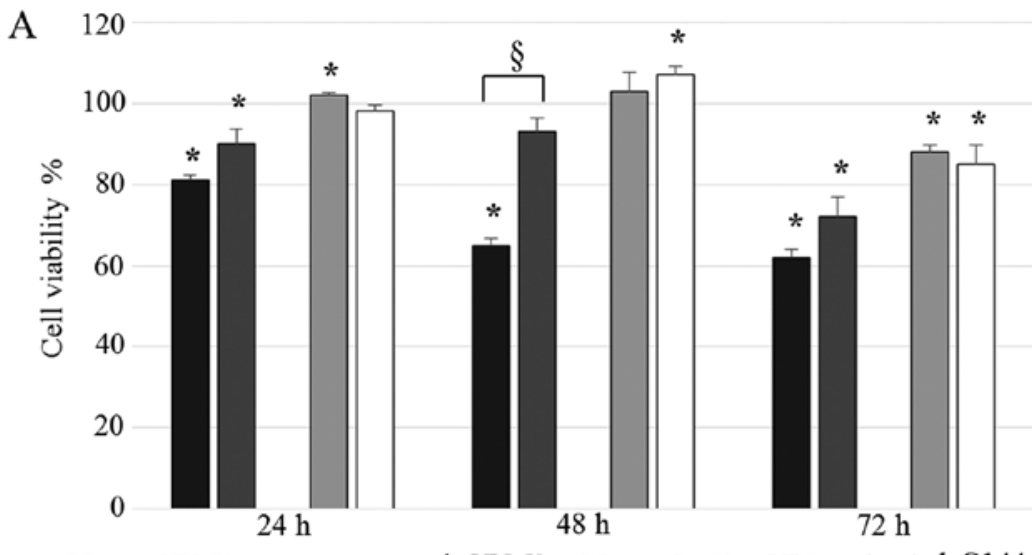

- Naïve GBM2 a VPA pretreated GBM2 $\square$ Naïve G144 $\square$ VPA pretreated G144
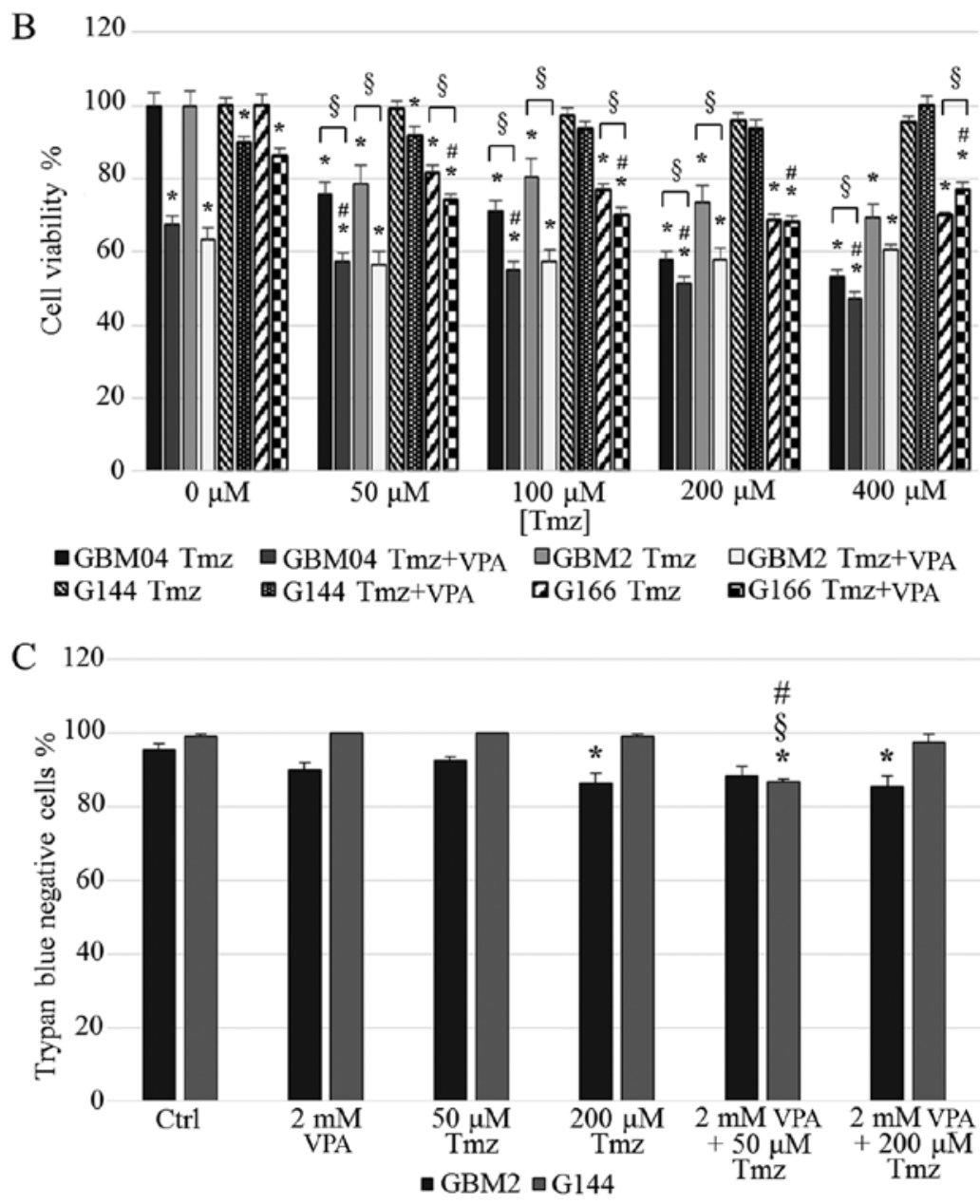

Figure 5. (A) Valproic acid (VPA) sensitivity in VPA pretreated and 'naïve' glioma stem cells (GSCs). (B) GSC viability after VPA or temozolomide (TMZ) single treatments and TMZ + VPA combined treatments. (C) Percentage of trypan blue-negative cells after VPA, TMZ and VPA + TMZ treatments compared to the untreated sample. (t-test: ${ }^{*} \mathrm{P}<0.05$ in untreated vs. treated cells; ${ }^{\circledR} \mathrm{P}<0.05$ in TMZ vs. VPA + TMZ; ${ }^{~} \mathrm{P}<0.05$ in VPA vs. VPA + TMZ).

G144 cell lines treated with only VPA or TMZ, and VPA plus TMZ. The percentage of live GBM2 cells after the combined treatments was slightly reduced with respect to the single treatments and the differences were not statistically significant. With regard to the percentage of live G144 cells after the combined treatments, we observed a weak decrease only in the $2 \mathrm{mM}$ VPA plus $50 \mu \mathrm{M}$ TMZ combination compared to the control culture and single treatments (13.4\%) (Fig. 5C).

\section{Discussion}

VPA is an approved drug for the treatment of epileptic seizures, and is effective for bipolar disorders and migraine. VPA is also an HDACi $(34,35)$ that has shown potent antitumor effects in vitro and in vivo in a variety of cancers, including $\operatorname{GBM}(36,37)$. This drug is a chromatin remodeling agent, consequently able to strongly modify gene expression (38-40), 
inducing cancer cell differentiation, apoptosis and growth arrest. We previously demonstrated that short-term VPA treatment is able to modulate the cancer stem-like properties of GSCs by its pro-differentiating ability, overcoming their perpetual stem cell state. In particular, VPA induced a sort of initial differentiation process and a sharp growth arrest (25).

The risk of GBM patients to experience epileptic seizures is in the range of $30-50 \%$ (41) and the majority are treated with VPA (42-44). For this reason, it is interesting to evaluate in vitro the potential effects of long-term VPA administration on GSCs, in order to also consider the application of this drug for anticancer purposes.

We firstly investigated the effects of long-term VPA treatment on cell morphology. As expected, the VPA prodifferentiating power was more marked after long-term treatment, with respect to short-term administration. Five out of seven GSC lines showed consistent morphological changes after 14 and 30 days (from rolling spheres to attached star-shaped cells with neurite-like structures), while in the G166 and GBM7 cell lines a cytotoxic effect or apoptosis prevailed following terminal differentiation. Overall, these results demonstrated that VPA induced several morphological variations, as previously described in other tumors (45): we speculated that the HDAC inhibitory action of VPA could trigger reactivation of genes involved in differentiation, usually silenced in cancer stem cells $(12,13)$. In fact, for example, after 30 days of treatment, we identified a potentially reactivating methylation change of OLIG1 and OLIG3 promoters, which are involved in oligodendrocyte and neuronal differentiation $(46,47)$, from the methylated to the unmethylated status in G144 and GBM2 cells, respectively (Table III).

The expression analysis of stemness and differentiation markers highlighted the variability of VPA pro-differentiating ability among the GSC lines; this issue is representative of GBM heterogeneity. In our previous study, the immunofluorescence analysis, performed after $2 \mathrm{mM}$ VPA for $72 \mathrm{~h}$, revealed the co-expression of stemness and differentiation markers (25). Therefore, in the present study, we investigated the expression of such markers after 14 and 30 days of treatment to verify the real capability of GSCs to terminally differentiate in the consequence of a long pro-differentiating stimulus. In particular, the G144 and GBM04 cell lines after 30 days expressed only one differentiation marker, GFAP or MBP respectively, suggesting peculiar differentiation behaviors towards the astrocytic and oligodendrocytic lineages. Conversely, the G166 cell line had a particular response; after 14 days it showed a high percentage of cells positive for the differentiation markers, while after 30 days, these cells did not express any one marker. We thus speculated that the G166 cell line is subjected to a transdifferentiation process (48). The analysis also revealed that 3 out of 6 cell lines maintained the co-expression of stemness and differentiation markers (GBM2, G179 and GliNS2), suggesting an impairment of any gene involved in the regulation of differentiation. Alternatively, resistance mechanisms to VPA may arise in these cell lines and VPA-resistant cells selectively grow during drug treatment $(49,50)$.

In the second instance, we analyzed the DNA methylation profiles of the GBM2 and G144 cell lines after $96 \mathrm{~h}$ and 30 days of VPA treatment to study and compare the epigenetic impacts of the two pharmacological regimens. Specifically, we selected two cell lines showing deep differences in VPA responsiveness in order to verify whether these features were consequent to a drug-specific activity on chromatin remodeling. Overall, VPA strongly modified the DNA methylation pattern of these cell lines. Our data confirmed the described VPA property to modify the methyloma $(51,52)$; it determines not only alterations in histone acetylation, but also, indirectly, changes in DNA methylation.

After $96 \mathrm{~h}$ of VPA treatment, the percentages of genes that modified their methylation status in the two cell lines could directly reflect their initial VPA sensitivity: we observed that $28.47 \%$ of genes had an altered methylation status in the GBM2 cell line, which is VPA sensitive, while few genes $(17.48 \%)$ were altered in the G144 cells, a resistant cell line. Furthermore, the different VPA susceptibilities of the two cell lines were also evidenced by the different trends in the methylation change after short-term treatment. In fact, in GBM2 cells, a high percentage of genes switched from an unmethylated to a methylated status (23.27\%), while the majority of 'modified' genes moved in the opposite direction compared with the G144 cells (11.82\%). The latter also maintained this issue after the long-term regimen. In contrast, the GBM2 modifying trend was completely revolutionized and became similar to the G144 behavior. The long-term exposure probably promotes in the GBM2 cell line the acquisition of resistance and the clonal expansion of resistant cells. This hypothesis was confirmed by the MTT assay in the GBMS cells folloiwng a 30-day VPA pretreatment, which showed a reduced sensitivity to $2 \mathrm{mM}$ VPA compared to the naïve cells.

Moreover, we observed by means of GO analysis that the 'development and differentiation' and 'neural differentiation and nervous system process' functional categories were the most represented ones, together with 'metabolism', after VPA treatments in both cell lines. These data further confirmed the VPA pro-differentiating ability on the GSC lines.

Nevertheless, it is important to explore the function and the role of genes influenced by these changes in regards to the methylation status after VPA treatment. Thus, we decided to investigate the methylation status of genes involved in critical signaling pathways important in GBM, such as MGMT, before and after short- and long-term treatments. MGMT promoter methylation is currently considered a predictive biomarker for the responsiveness to chemotherapy with alkylating agents such as TMZ; it is associated with an increased survival of GBM patients treated with TMZ $(33,53)$. In the present study, we found that VPA treatment for $96 \mathrm{~h}$ induced a methylation shift in the MGMT promoter only in the GBM2 cell line, from an unmethylated to a methylated status, while the long-term treatment did not modify the status. Conversely, G144 cells did not show any modification of MGMT promoter methylation after both regimens (methylated).

In consequence of these data, we finally verified whether a short-term VPA pretreatment is able to sensitize GSCs to TMZ. Here, we used VPA pretreatment, as a chemo-sensitizer, to augment TMZ sensitivity of the GBM2, G144, GBM04 and G166 cell lines. Unexpectedly, VPA did not produce any relevant increase in the TMZ efficacy in all cell lines in terms of metabolic activity and percentage of live cells. These data clearly indicate that the DNA methylation status of the MGMT promoter and its epigenetic switch induced by VPA 
are not the only determinant factors to predict and induce TMZ chemosensitivity of GSCs. A complex and extensive chemo-resistance landscape characterizes these cancer cells and other molecular mechanisms, such as the overexpression of p-glycoprotein (54), are involved in TMZ resistance (55-58).

The development of new therapeutic approaches that selectively target GSCs is mandatory to defeat GBM. Specifically, differentiation-inducing therapies are promising treatments to affect GSC self-renewal ability. Furthermore, restoring the physiological epigenetic pattern could be a useful strategy to fight GBM chemoresistance, yet it is unable to be the unique and definitive resolution to overcome this devastating feature. Short-term VPA treatment could combine in a single pharmacological regimen both of these two therapeutic strategies. Unfortunately, long-term VPA treatment induced the development of a resistant phenotype and, although the therapeutic properties and side effects of VPA are known since the 1970s, the question of whether a long-term antineoplastic treatment with this drug may be harmful for patients has never been exhaustively answered (59).

However, the overall data obtained warrant further investigation into the VPA effects on this fatal tumor in order to benefit patient prognosis. Additional in vitro and in vivo studies are necessary to clarify various key aspects of this pharmacological approach.

\section{Acknowledgements}

The authors gratefully acknowledge Professor Austin Smith (University of Cambridge, Cambridge, UK), ISE (Integrated Systems Engineering) and Dr Antonio Daga (IRCCS-AOU San Martino-IST, Genova, Italy) for kindly providing us with the cell lines used in this study. This study was supported by FAR 2011 n.12-1-62 and n.12-155 from the University of Milano-Bicocca (to L.D. and A.B., respectively) and by FIRB project from the Ministry of University and Scientific Research (to M.L.).

\section{References}

1. Louis DN, Ohgaki H, Wiestler OD, Cavenee WK, Burger PC, Jouvet A, Scheithauer BW and Kleihues P: The 2007 WHO classification of tumours of the central nervous system. Acta Neuropathol 114: 97-109, 2007.

2. Brandes AA, Franceschi E, Ermani M, Tosoni A, Albani F, Depenni R, Faedi M, Pisanello A, Crisi G, Urbini B, et al: Pattern of care and effectiveness of treatment for glioblastoma patients in the real world: Results from a prospective population-based registry. Could survival differ in a high-volume center? Neurooncol Pract 1: 166-171, 2014.

3. Nduom EK, Hadjipanayis CG and Van Meir EG: Glioblastoma cancer stem-like cells: Implications for pathogenesis and treatment. Cancer J 18: 100-106, 2012.

4. Sottoriva A, Spiteri I, Piccirillo SG, Touloumis A, Collins VP, Marioni JC, Curtis C, Watts C and Tavaré S: Intratumor heterogeneity in human glioblastoma reflects cancer evolutionary dynamics. Proc Natl Acad Sci USA 110: 4009-4014, 2013.

5. Piccirillo SG, Combi R, Cajola L, Patrizi A, Redaelli S, Bentivegna A, Baronchelli S, Maira G, Pollo B, Mangiola A, et al: Distinct pools of cancer stem-like cells coexist within human glioblastomas and display different tumorigenicity and independent genomic evolution. Oncogene 28: 1807-1811, 2009.

6. Esteller M: Epigenetics in cancer. N Engl J Med 358: 1148-1159, 2008.

7. Hatziapostolou M and Iliopoulos D: Epigenetic aberrations during oncogenesis. Cell Mol Life Sci 68: 1681-1702, 2011.
8. Nagarajan RP and Costello JF: Molecular epigenetics and genetics in neuro-oncology. Neurotherapeutics 6: 436-446, 2009.

9. Khan $\mathrm{O}$ and La Thangue NB: HDAC inhibitors in cancer biology: Emerging mechanisms and clinical applications. Immunol Cell Biol 90: 85-94, 2012.

10. Song SH, Han SW and Bang YJ: Epigenetic-based therapies in cancer: Progress to date. Drugs 71: 2391-2403, 2011.

11. Cinatl J Jr, Cinatl J, Scholz M, Driever PH, Henrich D, Kabickova H, Vogel JU, Doerr HW and Kornhuber B: Antitumor activity of sodium valproate in cultures of human neuroblastoma cells. Anticancer Drugs 7: 766-773, 1996.

12. Blaheta RA, Michaelis M, Driever PH and Cinatl J Jr: Evolving anticancer drug valproic acid: Insights into the mechanism and clinical studies. Med Res Rev 25: 383-397, 2005.

13. Van Lint C, Emiliani S and Verdin E: The expression of a small fraction of cellular genes is changed in response to histone hyperacetylation. Gene Expr 5: 245-253, 1996.

14. Chateauvieux S, Morceau F, Dicato M and Diederich M: Molecular and therapeutic potential and toxicity of valproic acid. J Biomed Biotechnol 2010: 479364, 2010.

15. Bacon CL, O'Driscoll E and Regan CM: Valproic acid suppresses G1 phase-dependent sialylation of a $65 \mathrm{kDa}$ glycoprotein in the C6 glioma cell cycle. Int J Dev Neurosci 15: 777-784, 1997.

16. Knüpfer MM, Hernáiz-Driever P, Poppenborg H, Wolff JE and Cinatl J: Valproic acid inhibits proliferation and changes expression of CD44 and CD56 of malignant glioma cells in vitro. Anticancer Res 18: 3585-3589, 1998.

17. Chavez-Blanco A, Perez-Plasencia C, Perez-Cardenas E, Carrasco-Legleu C, Rangel-Lopez E, Segura-Pacheco B, Taja-Chayeb L, Trejo-Becerril C, Gonzalez-Fierro A, Candelaria M, et al: Antineoplastic effects of the DNA methylation inhibitor hydralazine and the histone deacetylase inhibitor valproic acid in cancer cell lines. Cancer Cell Int 6: 2, 2006.

18. Das CM, Aguilera D, Vasquez H, Prasad P, Zhang M, Wolff JE and Gopalakrishnan V: Valproic acid induces p21 and topoisomerase-II (alpha/beta) expression and synergistically enhances etoposide cytotoxicity in human glioblastoma cell lines. J Neurooncol 85: 159-170, 2007.

19. Van Nifterik KA, Van den Berg J, Slotman BJ, Lafleur MV, Sminia P and Stalpers LJ: Valproic acid sensitizes human glioma cells for temozolomide and $\gamma$-radiation. J Neurooncol 107: 61-67, 2012.

20. Ryu CH, Yoon WS, Park KY, Kim SM, Lim JY, Woo JS Jeong $\mathrm{CH}$, Hou Y and Jeun SS: Valproic acid downregulates the expression of MGMT and sensitizes temozolomide-resistant glioma cells. J Biomed Biotechnol 2012: 987495, 2012.

21. Chen $\mathrm{CH}$, Chang YJ, Ku MS, Chung KT and Yang JT: Enhancement of temozolomide-induced apoptosis by valproic acid in human glioma cell lines through redox regulation. $\mathbf{J}$ Mol Med Berl 89: 303-315, 2011.

22. Pollard SM, Yoshikawa K, Clarke ID, Danovi D, Stricker S, Russell R, Bayani J, Head R, Lee M, Bernstein M, et al: Glioma stem cell lines expanded in adherent culture have tumor-specific phenotypes and are suitable for chemical and genetic screens. Cell Stem Cell 4: 568-580, 2009.

23. Griffero F, Daga A, Marubbi D, Capra MC, Melotti A, Pattarozzi A, Gatti M, Bajetto A, Porcile C, Barbieri F, et al: Different response of human glioma tumor-initiating cells to epidermal growth factor receptor kinase inhibitors. J Biol Chem 284: 7138-7148, 2009.

24. Baronchelli S, Bentivegna A, Redaelli S, Riva G, Butta V, Paoletta L, Isimbaldi G, Miozzo M, Tabano S, Daga A, et al: Delineating the cytogenomic and epigenomic landscapes of glioma stem cell lines. PLoS One 8: e57462, 2013.

25. Riva G, Baronchelli S, Paoletta L, Butta V, Biunno I, Lavitrano M, Dalprà $\mathrm{L}$ and Bentivegna $\mathrm{A}$ : In vitro anticancer drug test: A new method emerges from the model of glioma stem cells. Toxicol Rep 1: 188-199, 2014.

26. Aouali N, Palissot V, El-Khoury V, Moussay E, Janji B, Pierson S, Brons NH, Kellner L, Bosseler M, Van Moer K, et al: Peroxisome proliferator-activated receptor gamma agonists potentiate the cytotoxic effect of valproic acid in multiple myeloma cells. Br J Haematol 147: 662-671, 2009.

27. Straussman R, Nejman D, Roberts D, Steinfeld I, Blum B, Benvenisty N, Simon I, Yakhini Z and Cedar H: Developmental programming of $\mathrm{CpG}$ island methylation profiles in the human genome. Nat Struct Mol Biol 16: 564-571, 2009.

28. Beissbarth T and Speed TP: GOstat: Find statistically overrepresented Gene Ontologies within a group of genes. Bioinformatics 20: 1464-1465, 2004. 
29. Kanu OO, Hughes B, Di C, Lin N, Fu J, Bigner DD, Yan H and Adamson C: Glioblastoma multiforme oncogenomics and signaling pathways. Clin Med Oncol 3: 39-52, 2009.

30. Wardak Z and Choe KS: Molecular pathways and potential therapeutic targets in glioblastoma multiforme. Expert Rev Anticancer Ther 13: 1307-1318, 2013.

31. Stupp R, Mason WP, van den Bent MJ, Weller M, Fisher B, Taphoorn MJ, Belanger K, Brandes AA, Marosi C, Bogdahn U, et al; European Organisation for Research and Treatment of Cancer Brain Tumor and Radiotherapy Groups; National Cancer Institute of Canada Clinical Trials Group: Radiotherapy plus concomitant and adjuvant temozolomide for glioblastoma. $\mathrm{N}$ Engl J Med 352: 987-996, 2005.

32. Zhang J, Stevens MF and Bradshaw TD: Temozolomide: Mechanisms of action, repair and resistance. Curr Mol Pharmacol 5: 102-114, 2012.

33. Hegi ME, Diserens AC, Gorlia T, Hamou MF, de Tribolet N, Weller M, Kros JM, Hainfellner JA, Mason W, Mariani L, et al: MGMT gene silencing and benefit from temozolomide in glioblastoma. N Engl J Med 352: 997-1003, 2005.

34. Göttlicher M, Minucci S, Zhu P, Krämer OH, Schimpf A, Giavara S, Sleeman JP, Lo Coco F, Nervi C, Pelicci PG, et al: Valproic acid defines a novel class of HDAC inhibitors inducing differentiation of transformed cells. EMBO J 20: 6969-6978, 2001.

35. Phiel CJ, Zhang F, Huang EY, Guenther MG, Lazar MA and Klein PS: Histone deacetylase is a direct target of valproic acid, a potent anticonvulsant, mood stabilizer, and teratogen. J Biol Chem 276: 36734-36741, 2001

36. Osuka S, Takano S, Watanabe S, Ishikawa E, Yamamoto T and Matsumura A: Valproic acid inhibits angiogenesis in vitro and glioma angiogenesis in vivo in the brain. Neurol Med Chir (Tokyo) 52: 186-193, 2012.

37. Knüpfer MM, Pulzer F, Schindler I, Hernaíz Driever P, Knüpfer H and Keller E: Different effects of valproic acid on proliferation and migration of malignant glioma cells in vitro. Anticancer Res 21: 347-351, 2001.

38. Cameron EE, Bachman KE, Myöhänen S, Herman JG and Baylin SB: Synergy of demethylation and histone deacetylase inhibition in the re-expression of genes silenced in cancer. Nat Genet 21: 103-107, 1999.

39. De la Cruz-Hernández E, Perez-Plasencia C, Pérez-Cardenas E, Gonzalez-Fierro A, Trejo-Becerril C, Chávez-Blanco A, Taja-Chayeb L, Vidal S, Gutiérrez O, Dominguez GI, et al: Transcriptional changes induced by epigenetic therapy with hydralazine and magnesium valproate in cervical carcinoma. Oncol Rep 25: 399-407, 2011.

40. Suzuki H, Gabrielson E, Chen W, Anbazhagan R, van Engeland M, Weijenberg MP, Herman JG and Baylin SB: A genomic screen for genes upregulated by demethylation and histone deacetylase inhibition in human colorectal cancer. Nat Genet 31: 141-149, 2002.

41. van Breemen MS, Wilms EB and Vecht CJ: Epilepsy in patients with brain tumours: Epidemiology, mechanisms, and management. Lancet Neurol 6: 421-430, 2007.

42. Sizoo EM, Koekkoek JA, Postma TJ, Heimans JJ, Pasman HR, Deliens L, Taphoorn MJ and Reijneveld JC: Seizures in patients with high-grade glioma: A serious challenge in the end-of-life phase. BMJ Support Palliat Care 4: 77-80, 2014.

43. Guthrie GD and Eljamel S: Impact of particular antiepileptic drugs on the survival of patients with glioblastoma multiforme. J Neurosurg 118: 859-865, 2013.

44. Vecht CJ, Kerkhof M and Duran-Pena A: Seizure prognosis in brain tumors: New insights and evidence-based management. Oncologist 19: 751-759, 2014.

45. Duenas-Gonzalez A, Candelaria M, Perez-Plascencia C, Perez-Cardenas E, de la Cruz-Hernandez E and Herrera LA: Valproic acid as epigenetic cancer drug: Preclinical, clinical and transcriptional effects on solid tumors. Cancer Treat Rev 34: 206-222, 2008
46. Dai J, Bercury KK, Ahrendsen JT and Macklin WB: Olig1 function is required for oligodendrocyte differentiation in the mouse brain. J Neurosci 35: 4386-4402, 2015.

47. Liu Z, Li H, Hu X, Yu L, Liu H, Han R, Colella R, Mower GD, Chen Y and Qiu M: Control of precerebellar neuron development by Olig3 bHLH transcription factor. J Neurosci 28: 10124-10133, 2008.

48. Soda Y, Marumoto T, Friedmann-Morvinski D, Soda M, Liu F, Michiue H, Pastorino S, Yang M, Hoffman RM, Kesari S, et al: Transdifferentiation of glioblastoma cells into vascular endothelial cells. Proc Natl Acad Sci USA 108: 4274-4280, 2011.

49. Liu T, Liu PY, Tee AE, Haber M, Norris MD, Gleave ME and Marshall GM: Over-expression of clusterin is a resistance factor to the anti-cancer effect of histone deacetylase inhibitors. Eur J Cancer 45: 1846-1854, 2009.

50. Juengel E, Makarević J, Tsaur I, Bartsch G, Nelson K, Haferkamp A and Blaheta RA: Resistance after chronic application of the HDAC-inhibitor valproic acid is associated with elevated Akt activation in renal cell carcinoma in vivo. PLoS One 8: e53100, 2013

51. Milutinovic S, D'Alessio AC, Detich N and Szyf M: Valproate induces widespread epigenetic reprogramming which involves demethylation of specific genes. Carcinogenesis 28: 560-571, 2007.

52. Detich N, Bovenzi V and Szyf M: Valproate induces replication-independent active DNA demethylation. J Biol Chem 278: 27586-27592, 2003.

53. Brandes AA, Franceschi E, Tosoni A, Blatt V, Pession A, Tallini G, Bertorelle R, Bartolini S, Calbucci F, Andreoli A, et al: MGMT promoter methylation status can predict the incidence and outcome of pseudoprogression after concomitant radiochemotherapy in newly diagnosed glioblastoma patients. J Clin Oncol 26: 2192-2197, 2008

54. Munoz JL, Rodriguez-Cruz V, Greco SJ, Nagula V, Scotto KW and Rameshwar P: Temozolomide induces the production of epidermal growth factor to regulate MDR1 expression in glioblastoma cells. Mol Cancer Ther 13: 2399-2411, 2014.

55. Munoz JL, Rodriguez-Cruz V, Greco SJ, Ramkissoon SH, Ligon KL and Rameshwar P: Temozolomide resistance in glioblastoma cells occurs partly through epidermal growth factor receptor-mediated induction of connexin 43. Cell Death Dis 5: e1145, 2014.

56. Munoz JL, Walker ND, Scotto KW and Rameshwar P: Temozolomide competes for P-glycoprotein and contributes to chemoresistance in glioblastoma cells. Cancer Lett 367: 69-75, 2015.

57. Tivnan A, Zakaria Z, O'Leary C, Kögel D, Pokorny JL, Sarkaria JN and Prehn JH: Inhibition of multidrug resistance protein 1 (MRP1) improves chemotherapy drug response in primary and recurrent glioblastoma multiforme. Front Neurosci 9: 218, 2015.

58. Kitange GJ, Mladek AC, Carlson BL, Schroeder MA, Pokorny JL, Cen L, Decker PA, Wu W, Lomberk GA, Gupta SK, et al: Inhibition of histone deacetylation potentiates the evolution of acquired temozolomide resistance linked to MGMT upregulation in glioblastoma xenografts. Clin Cancer Res 18: 4070-4079, 2012.

59. Zighetti ML, Fontana G, Lussana F, Chiesa V, Vignoli A, Canevini MP and Cattaneo M: Effects of chronic administration of valproic acid to epileptic patients on coagulation tests and primary hemostasis. Epilepsia 56: e49-e52, 2015. 